\title{
Cymantrene, Cyrhetrene and Ferrocene Nucleobase Conjugates: Synthesis, Structure, Computational Study, Electrochemistry and Antitrypanosomal Activity
}

Konrad Kowalski, ${ }^{[\mathrm{a}] *}$ Lukasz Szczupk, ${ }^{[\mathrm{a}]}$ Sebastian Saloman, ${ }^{[\mathrm{b}]}$ Dietmar Steverding, ${ }^{[\mathrm{c}]}$ Artur Jabłoński, ${ }^{[\mathrm{a}]}$ Valerije Vrček, ${ }^{[\mathrm{d}]}$ Alexander Hildebrandt, ${ }^{[\mathrm{b}]}$ Heinrich Lang, ${ }^{[\mathrm{b}]}$ Agnieszka Rybarczyk-Pirek ${ }^{\text {[e] }}$

${ }^{[\mathrm{a}]}$ Faculty of Chemistry, Department of Organic Chemistry, University of Łódź, Tamka 12, PL-91403 Łódź, Poland

${ }^{[b]}$ Technische Universität Chemnitz, Faculty of Natural Sciences, Institute of Chemistry, Inorganic Chemistry, D-09107 Chemnitz, Germany

${ }^{[c]}$ Bob Champion Research \& Education Building, Norwich Medical School, University of East Anglia, Norwich Research Park, Norwich NR4 7UQ, United Kingdom

${ }^{[d]}$ Faculty of Pharmacy and Biochemistry, University of Zagreb, Ante Kovačića 1, Zagreb, Croatia

${ }^{[\mathrm{e}]}$ Faculty of Chemistry, Department of Theoretical and Structural Chemistry, Pomorska 163/165, PL-90236 Lódź, Poland 
Abstract: A series of eleven cymantrene- and cyrhetrene-nucleobase conjugates together with the hitherto unreported $N 7$-isomer of the ferrocene-adenine conjugate have been synthesised and characterized. The synthetic approach involved a Michael addition reaction of in situ generated acryloylcymantrene, acryloylcyrhetrene and acryloylferrocene with canonical nucleobases, such as thymine, uracil and adenine, respectively. The mechanism of these reactions was investigated by means of density functional theory (DFT) calculations. The respective products were characterized by spectroscopic methods and by electrochemical measurements. The molecular structure of one cymantrene-adenine conjugate (5) in the solid state was determined by single-crystal X-ray structure analysis, confirming the N9substitution mode of the adenine moiety. It was found that the molecule adopts a bent conformation with the adenine and cyclopentadienyl planes in almost perpendicular orientation. The cymantrenyl nucleobases showed an irreversible redox behaviour which is associated with ligand exchange reactions of the radical cationic species. The newly synthesised compounds were also tested for their activity against the protozoan parasite Trypanosoma brucei and human myeloid leukaemia HL-60 cells. Some compounds showed promising antitrypanosomal activity while most of them were non-toxic to HL-60 cells. It was additionally found that cymantrene and cyrhetrene ketone nucleobases were more active than their alcohol congeners. These findings indicate the potential of cymantrene and cyrhetrene nucleobase conjugates as possible lead compounds for future antitrypanosomal drug development. 


\section{Introduction}

The significance of organometallic complexes in biological applications have increased over the last decade. ${ }^{[1]}$ They have been profoundly examined as anticancer agents ${ }^{[2]}$ and there is also a growing interest in their antibacterial ${ }^{[3]}$ and antiparasitic ${ }^{[4]}$ applications. Furthermore, organometallic complexes are utilized as probes for single-cell bioimaging ${ }^{[5]}$ and as photoactivated anticancer agents with potential use in photodynamic therapy $(\mathrm{PDT})^{[6]}$ and photoactivated chemotherapy (PACT). ${ }^{[7]}$

Cyclopentadienyl manganese tricarbonyl (= cymantrene) and cyclopentadienyl rhenium tricarbonyl (= cyrhetrene) half-sandwich piano-stool-structured compounds have recently received much attention towards biological applications. This field has been extensively reviewed, providing numerous interesting examples. ${ }^{[1 \mathrm{~b}-\mathrm{c}, 8]}$ Some recent biological applications of cymantrene and cyrhetrene include their use as redox-active building blocks in the synthesis of tamoxifen anticancer drug derivatives. ${ }^{[9]}$ The anodic electrochemistry of such half-sandwich tamoxifen congeners was studied by combined cyclic voltammetry $(=\mathrm{CV})$ and IR spectroelectrochemistry. ${ }^{[9]}$ Furthermore, subcellular imaging of a cyrhetrenyl-tamoxifen derivative in human MDA-MB-231 cancer cells was recently achieved by using an advanced photothermally induced resonance technique. ${ }^{[10]}$ Labelling of hormone steroids with a nonradioactive cyrhetrenyl moiety has significant impact on the design of ${ }^{99 \mathrm{~m}} \mathrm{Tc}$ radionuclide contrast agents for positron emission tomography (= PET) and on the development of ${ }^{186 / 188} \mathrm{Re}$ radiopharmaceuticals. $^{[11]}$ In addition, cyrhetrene-arylsulfonamide, -arylsulfamide and arylsulfamate compounds have been shown to inhibit human carbonic anhydrase (hCA) enzymes in the low nanomolar range. ${ }^{[12]}$ X-ray crystal structure analysis of cyrhetrenyl inhibitor/hCAII-complexes confirmed binding of the inhibitor in the active site of the enzyme. ${ }^{[12]}$ It was shown that the half-sandwich cyrhetrenyl group bound to the three active site amino acids solely via hydrophobic interactions. ${ }^{[12]}$ Also, conjugation of cymantrenyl and 
cyrhetrenyl groups to peptides became a fruitful strategy for obtaining compounds with significant cytotoxicity. ${ }^{[13,14]}$ Specifically, it has been demonstrated that the attachment of the cymantrenyl entity to cell-penetrating peptides yields cytotoxic anticancer conjugates that show enhanced accumulation in the nucleus of cancer cells. ${ }^{[14]}$ Cymantrenyl and cyrhetrenyl groups have also been successfully utilized in the synthesis of a new generation of antibacterial agents. ${ }^{[15]}$ They show a new mechanisms of activity ${ }^{[15 b]}$ and the half-sandwich group is often essential for the bactericidal effect. ${ }^{[15 c]}$ Therapeutic properties of cymantrene and cyrhetrene complexes against malaria, leishmaniasis and trypanosomiasis is another area of application for these compounds. ${ }^{[16]}$ In this respect, cymantrenes and cyrhetrenes derived from 5-nitrofuran, ${ }^{[16 b, c]} 4$-aminoquinolines ${ }^{[16 \mathrm{~d}]}$ and triazoles ${ }^{[16 \mathrm{e}]}$ have been reported to display antitrypanosomal activity against Trypanosoma cruzi and $T$. brucei species.

The above mentioned examples show that functionalization of cymantrene and cyrhetrene cores with adequately designed substituents can lead to molecules with highly specific biological function. Accordingly, herein we report the synthesis, structure, density functional theory calculations and electrochemistry of cymantrene- and cyrhetrene-nucleobases (nucleobase $=$ uracil, thymine, adenine). In addition, the hitherto unreported $N 7$-isomer of a ferrocene-adenine compound is also reported.

Our interest in half-sandwich cymantrene and cyrhetrene-nucleobase compounds stems from the biological importance of closely related ferrocenyl-nucleobase conjugates. ${ }^{[17 a]}$ Representatives of ferrocene-nucleobase conjugates have been shown to exhibit significant anticancer $^{[17 \mathrm{~b}-\mathrm{d}]}$ and antibacterial ${ }^{[17 \mathrm{~d}]}$ activity. Within this contribution the antitrypanosomal activity of cymantrene- and cyrhetrene-nucleobases against T. brucei is reported along with their in vitro anticancer activity against human HL-60 cells. To the best of our knowledge this is the first report on cymantrenyl- and cyrhetrenyl-nucleobase conjugates and their properties. 


\section{Results and Discussion}

In the initial stage of our studies cymantrene-pyrimidines (pyrimidine $=$ thymine $(3)$ or uracil (4)), cymantrene-adenine (5) and cyrhetrene-pyrimidines (pyrimidine $=$ thymine $(\mathbf{6})$ or uracil (7)) were consecutively obtained in two steps according to Scheme 1. At first, chloropropionyl-cymantrene (1) and chloropropionyl-cyrhetrene (2) were prepared in a straightforward manner under common Friedel-Crafts reaction conditions. ${ }^{[18]}$ The following step involved a Michael addition of the nucleobase group and an in situ generated acryloylcymantrene and acryloylcyrhetrene species. ${ }^{[17 \mathrm{a}, \mathrm{d}]}$ The two "acryloyl" Michael acceptors were formed from the chloropropionyls $\mathbf{1}$ and $\mathbf{2}$ in a dehydrohalogenation reaction. After appropriate workup, cymantrenes 3 - 5 were isolated as yellow solids in a yield of 89, 64 or $60 \%$ (Experimental Section), respectively. Cyrhetrenes 6 and 7 were isolated as colourless solids in good yields (Experimental Section).

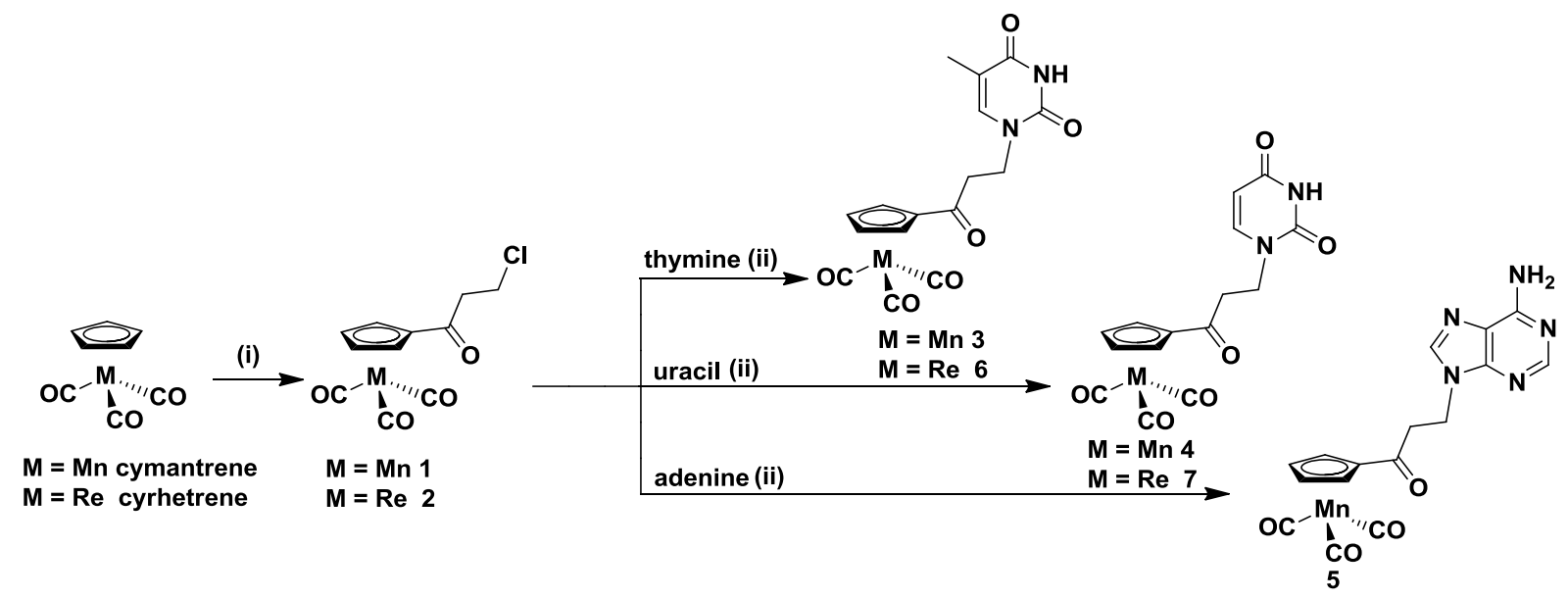

Scheme 1 Synthesis of 3-7 (DCM = dichloromethane, DMF = dimethylformamide; (i) 3chloropropionyl chloride, $\mathrm{AlCl}_{3}, \mathrm{DCM}$, ambient temperature, $5 \mathrm{~h}$; (ii) $\mathrm{Et}_{3} \mathrm{~N}, \mathrm{DMF}, 75^{\circ} \mathrm{C}, 5 \mathrm{~h}$ ).

In extension to the synthetic methodology used in the preparation of 3-7, the reaction of chloropropionyl-ferrocene (8) with adenine was conducted (Scheme 2). This reaction afforded the known N9-isomer $\mathbf{9}^{[19]}$ in $27 \%$ yield and the new N7-isomer $\mathbf{1 0}$ in a yield of $10 \%$. Both 
ferrocene derivatives were obtained as air-stable orange solids. The formation of the two isomers 9 and $\mathbf{1 0}$ contrasted the sole formation of isomer 5 (Scheme 1). To explain this inconsistency, the mechanism of both reactions was comparatively examined by means of DFT calculations (see below).

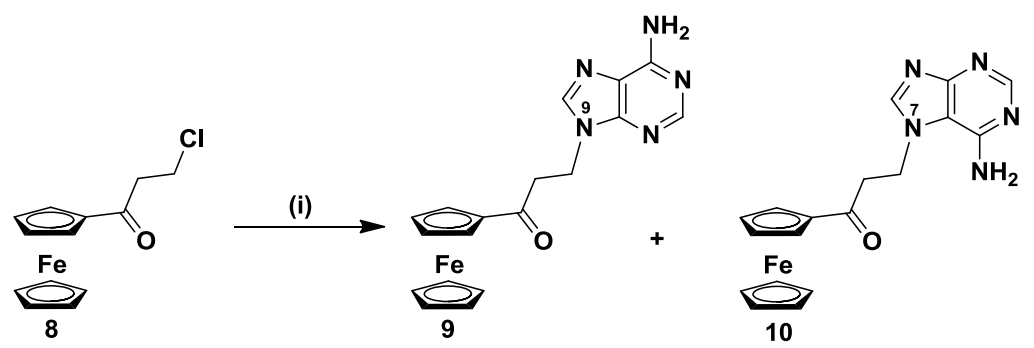

Scheme 2 Synthesis of 9 and $\mathbf{1 0}$ ((i) adenine, Et $\left.{ }_{3} \mathrm{~N}, \mathrm{DMF}, 75^{\circ} \mathrm{C}, 4 \mathrm{~h}\right)$.

In the following, compounds 3-7 were reduced to furnish the corresponding alcohols 11-14 (Scheme 3). This transformation was achieved by treatment of $\mathbf{3}-\mathbf{7}$ with sodium tetrahydridoborate in tetrahydrofuran.

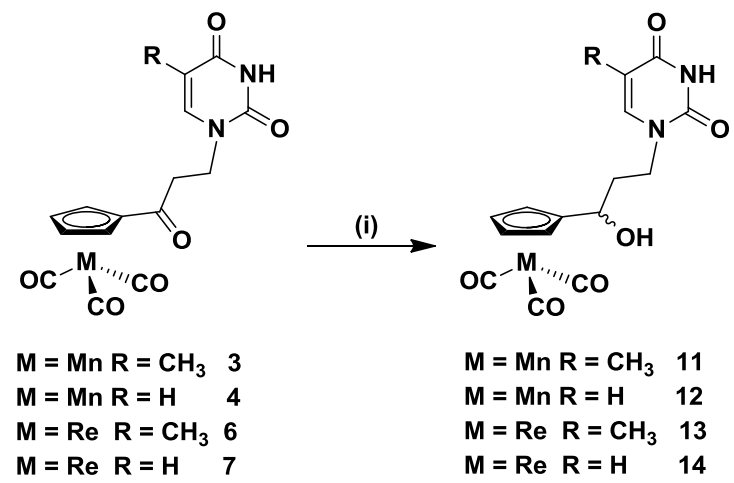

Scheme 3 Synthesis of 11-14 ((i) $\mathrm{Na}\left[\mathrm{BH}_{4}\right]$, THF, $1 \mathrm{~h}$, ambient temperature, then water).

After appropriate work-up, cymantrenyl alcohols $\mathbf{1 1}$ and $\mathbf{1 2}$ were isolated as yellow solids (ca. 55\% yield), while the corresponding cyrhetrenes $\mathbf{1 3}$ and $\mathbf{1 4}$ were obtained as colourless solids in a yield of approximately $80 \%$. However, treatment of the cymantrenyl-adenine 5 
with $\mathrm{Na}\left[\mathrm{BH}_{4}\right]$ in tetrahydrofuran failed to give alcohol 15. To overcome this, an alternative reducing agent was applied. Accordingly, treatment of 5 with $\mathrm{Li}\left[\mathrm{AlH}_{4}\right]$ afforded corresponding $\mathbf{1 5}$ as a yellow solid in a yield of $81 \%$ (Scheme 4).
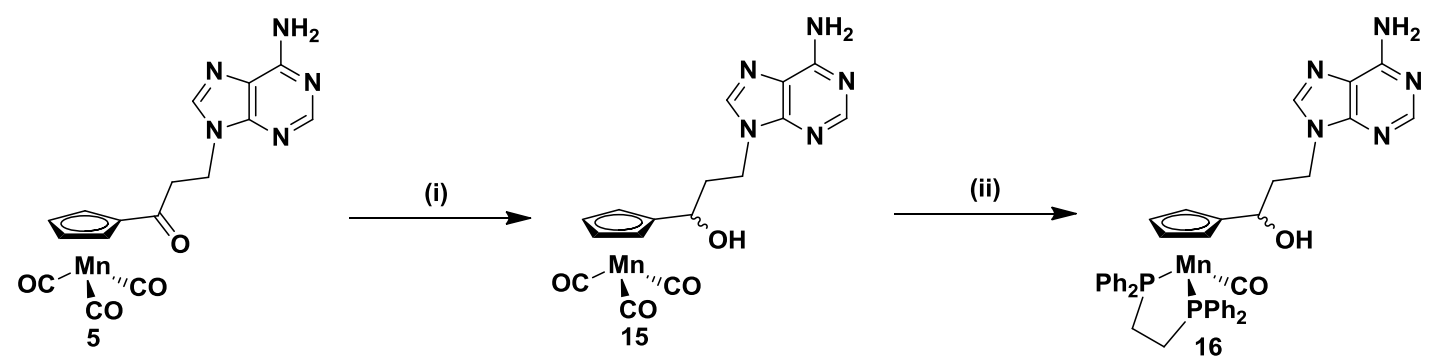

Scheme 4 Synthesis of $\mathbf{1 5}$ and $\mathbf{1 6}$ (dppe = 1,2-bis(diphenylphosphino)ethane) ((i) $\mathrm{Li}\left[\mathrm{AlH}_{4}\right]$, THF, $8 \mathrm{~min}$, ambient temperature, then methanol/water mixture of ratio 1:1 (v/v); (ii) dppe, hv, THF, 2 h, ambient temperature).

In addition, $\mathrm{CO}$ ligand substitution in $\mathbf{1 5}$ was examined. Ligand exchange reactions of cymantrene compounds occur under photochemical reaction conditions. ${ }^{[20]}$ It is typical that shorter times of irradiation results in the formation of mono-substituted species, while longer exposure times favour the formation of di-substituted products. In our case, a tetrahydrofuran solution of alcohol 15 and 1,2-bis(diphenylphosphino)ethane was photolysed with a $200 \mathrm{~W}$ high-pressure mercury lamp for $2 \mathrm{~h}$ to obtain 16 (Scheme 4). After appropriate workup, compound $\mathbf{1 6}$ was isolated as an orange solid in a yield of $37 \%$.

The identity of 1-7 and 9-16 was confirmed by NMR $\left({ }^{1} \mathrm{H},{ }^{13} \mathrm{C}\right)$ and IR spectroscopy, mass spectrometry, and elemental analysis. The analytical data confirm the proposed structures. In addition, the structure of $\mathbf{5}$ in the solid-state was determined by single-crystal X-ray crystallography. 


\section{Crystal structure}

Single crystals of $\mathbf{5}$ suitable for X-ray diffraction analysis were obtained by slow diffusion of hexane into a dichloromethane solution of $\mathbf{5}$. The oak ridge thermal-ellipsoid plot (ORTEP) drawing with the atom labelling scheme is shown in Figure 1, together with selected bond lengths and angles. Crystal and structure refinement data are attached in the ESI (Table S1).

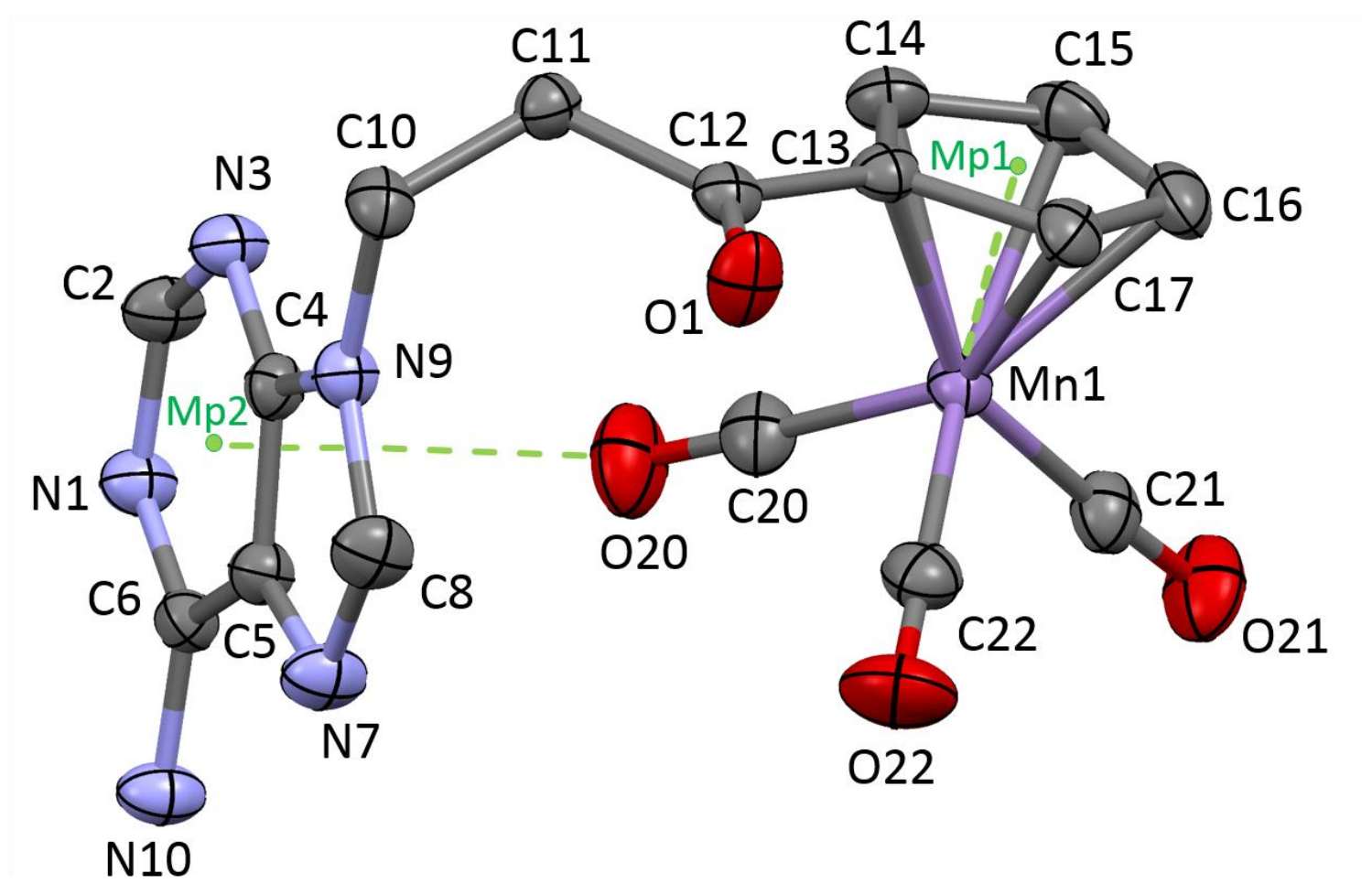

Figure 1 ORTEP diagram of 5 at 50\% probability level; Mp1 and Mp2 correspond to midpoints of the respective rings. Hydrogen atoms have been omitted for clarity. Selected bond lengths $(\AA)$ and angles $\left({ }^{\circ}\right)$ : Mn1-Mp1, 1.764(3); O20-Mp2, 3.19(2); Mn1-C13, 2.124(2); Mn1-C14, 2.143(2); Mn1-C22, 1.791(2); Mn1-C20, 1.805(2); O20-C20; 1.143(2); C12-C13, 1.477(2); C12-O1, 1.221(2); C10-N9, 1.451(2); N1-C6, 1.356(2); C13-C12-C11-C10, 152.4(2); C12-C11-C10-N9, -74.4(2); C11-C10-N9-C8, 106.8(2); C20-O20...Mp2, 128.7(2). 
The X-ray crystal structure analysis confirmed that the cymantrenyl moiety binds to the N9-position (Figure 1) of the adenine nucleobase. The manganese atom Mn1 is bonded to the cyclopentadienyl $(\mathrm{Cp})$ group and to the three carbonyl groups in a typical three-legged pianostool fashion. The Mn-C(carbonyl) bond distances (1.805(2), 1.801(2), 1.791(2)) and Mn$\mathrm{C}(\mathrm{Cp})$ bond distances $(2.124(2), 2.143(2), 2.152(2), 2.142(2), 2.129(2))$ are close to that of known cymantrene derivatives. ${ }^{16 \mathrm{~d}, \mathrm{e}}$ The carbonyl group of the hydrocarbyl linker is nearly coplanar with the $\mathrm{Cp}$ plane. Bond lengths and angels of the adenine group are unexceptional and need no further discussion. The most interesting feature of the crystal structure is the close spatial arrangement of the adenine and the cymantrenyl group linked by the hydrocarbyl chain. Accordingly, the plane of the adenine and the cyclopentadienyl group are almost perpendicular with a dihedral angle equal to $87.4(2)^{\circ}$. This molecular conformation is stabilized by intramolecular contact between the oxygen carbonyl atom O20 and the adenine ring. The $\mathrm{O} 20 \ldots \mathrm{Mp} 2$ distance is equal to 3.19(2) $\AA$ and the corresponding C20-O20...Mp2 angle is $128.7(2)^{\circ}(\mathrm{Mp} 2$ is the mid-point of the six-membered ring of the adenine group). The absolute value of the dihedral angle between the adenine and the cymantrenyl groups along the $\mathrm{C} 10-\mathrm{C} 11$ bond is $74.4(2)^{\mathrm{o}}$. Details of intermolecular interactions in the crystal structure of 5 are given in SI (Table S2, Figs. S16, S17).

\section{DFT calculations}

Steric and electronic effects have been considered computationally to rationalize the experimental finding that both N9- and N7-isomers (9 and 10) have been isolated in the reaction of adenine with chloropropionyl-ferrocene $\mathbf{8}$, while in the reaction of adenine with chloropropionyl-cymantrene $\mathbf{1}$ only the N9-isomer $\mathbf{5}$ was formed. The observed regioselectivity has been interpreted in terms of thermodynamic and kinetic control of the reaction. 
Steric Effects. A large difference in relative energies was calculated for the N7- and N9substituted adenines (Table S3; ESI and Scheme 5). The substitution in adenine at the N7position is attributed with an unfavorable steric repulsion between the N7-substituent and the amino group at C6 position, making the N9-isomers thermodynamically more stable. A minor stabilization of the N7-isomer in $\mathbf{1 0}$ can be explained by the more favorable interaction between the amine $\mathrm{N}-\mathrm{H}$ bond and the carbonyl oxygen atom, which preferentially stabilizes the N7-isomer (Figure 3).

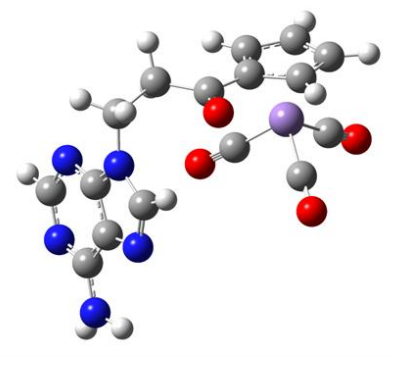

5

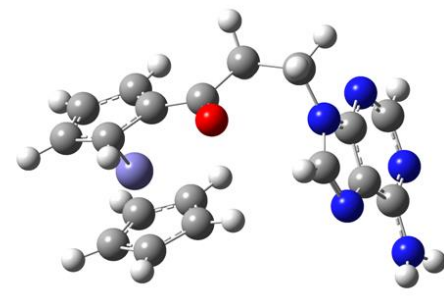

9

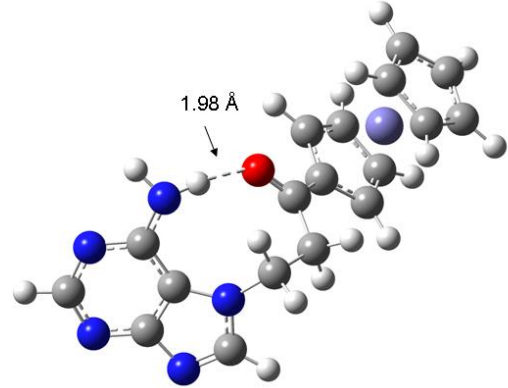

10

Figure 3 The most stable conformations of 5, 9 and $\mathbf{1 0}$ formed in the Michael addition of adenine to chloropropionyl-cymantrene (formation of 5) and adenine to chloropropionylferrocene (9 and 10) optimized at the B3LYP/6-31+G(d) level of theory. The $\mathrm{H}$ bonding between the amine hydrogen and carbonyl oxygen is indicated by the dashed line.

Kinetic vs thermodynamic control of the Michael reactions. Steric effects in N7- and N9substituted compounds are not sufficiently enough to explain the observed regioselectivity in the reaction between adenine with $\mathbf{1}$ and $\mathbf{8}$. If the reaction is thermodynamically driven, the N9-isomer would result as the only product (Table S3). However, our product analysis suggests that other issues than thermodynamic product stability should be considered. To rationalize the experimental observation, the kinetic competition between the two reactions was evaluated by means of DFT calculations. 
Acryloylferrocene. The nucleophilic reaction between the adenine anion follows the classic $\beta$ addition reaction, i.e., 1,4-conjugate addition. The adenine anion is an ambident nucleophile and can react at the N7- or N9-position. The corresponding transition state structures TS-N7 Fc and TS-N9Fc (Figure 4) for the two parallel processes have been located and compared in energy (Scheme 5). It was found that the Michael addition which involves the N7-reactive center is the kinetically preferred process. The calculated barrier $\left(\Delta G^{t}=101.1 \mathrm{~kJ} / \mathrm{mol}\right)$ is with 4.7 $\mathrm{kJ} / \mathrm{mol}$ lower than the barrier for the process in which the $\mathrm{N} 9$-nitrogen atom acts as a nucleophile. According to the transition state theory this energy barrier difference corresponds to the calculated ratio of rate constants $k_{\mathrm{N} 7} / k_{\mathrm{N} 9} \approx 5$. Therefore, the N7-product $\mathbf{1 0}$ is somewhat faster formed, yet the N9-product 9 is much more thermodynamically stable. This explains the experimental yield proportion of $\mathbf{9}$ to $\mathbf{1 0}$ of ca. 3 .

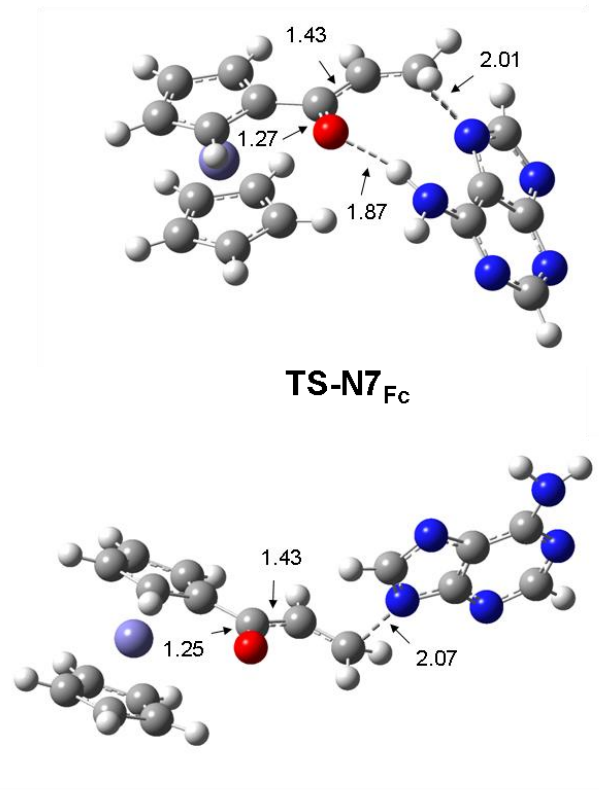

TS-N9 $9_{\mathrm{Fc}}$
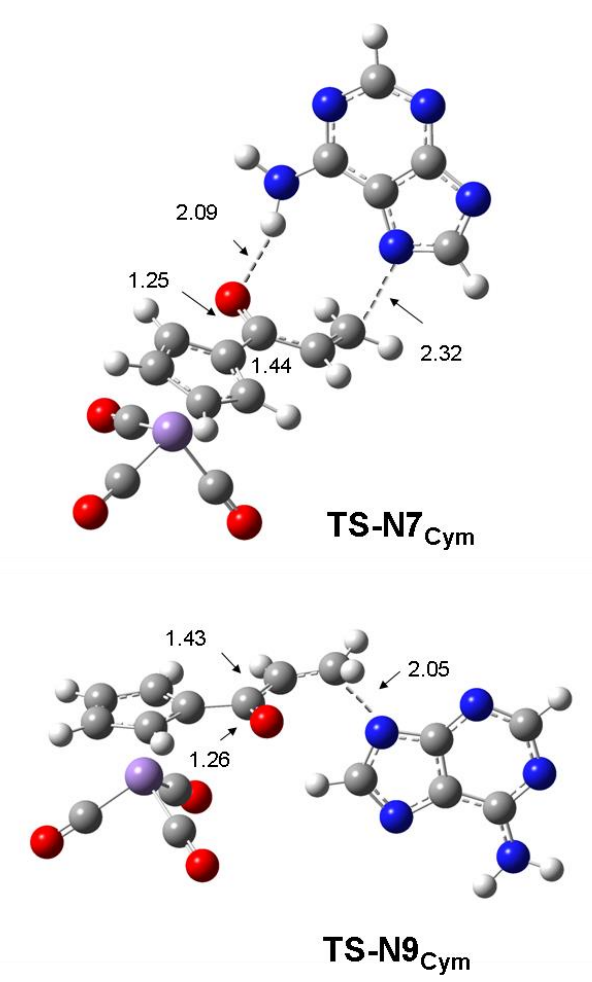

Figure 4. B3LYP/6-31+G(d) optimized transition state structures for the Michael addition reaction of the adenine anion to acryloylferrocene (formation of TS-N7 $\mathbf{F c}$ and TS-N9 $\mathbf{F c}$ ) and to acryloylcymantrene (TS-N7 $\mathbf{C y m}$ and TS-N9 Cym). All distances are in Ångstrom. 
Both transition structures TS-N7Fc and TS-N9 $\mathbf{F c}$ are characterized by the $s$-cis orientation of the acryloyl fragment and by imaginary frequencies (196i and $199 i \mathrm{~cm}^{-1}$, respectively) which correspond to $\mathrm{N}-\mathrm{C}$ bond formation concomitant with the enolization of the acryloyl moiety. It is interesting to note that the N7-reactive center in TS-N7Fc approaches the acryloyl ferrocene in an endo fashion, whereas the exo attack is favored in TS-N9Fc. The preference of the N7 attack (vs. N9) is likely due to intermolecular CO...HN hydrogen bond formation in TS-N7Fe.

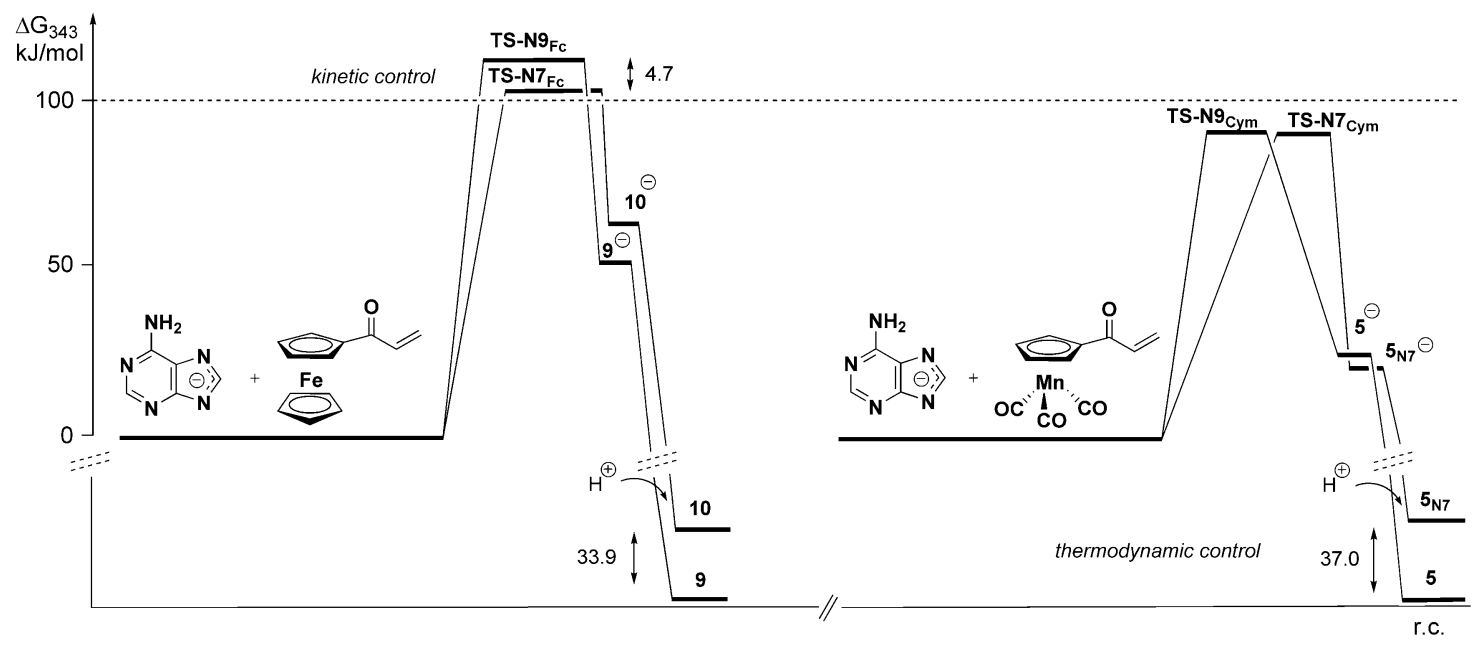

Scheme 5 Free energy profile (calculated at the CPCM-B3LYP/6-31+G(d) level) for two Michael addition reactions in which N7 and N9 products are formed. The energies of the reactant pairs of adenine anion/acryloylcymantrene and adenine anion/acryloylferrocene are arbitrarily set to zero for comparative purposes. The stationary points between the transition states and the final products correspond to enolate intermediates, as evidenced by the IRC procedure.

Acryloylcymantrene. In case of the acryloylcymantrene, two Michael addition reactions are possible, but only the reaction at the N9-position seems most likely, since the N9-isomer was isolated as main product. Transition state structures for the two reactions are very similar in energy $\left(\Delta \Delta G^{t}=0.4 \mathrm{~kJ} / \mathrm{mol}\right)$, which suggests that the exclusive formation of $\mathbf{5}$ is not under 
kinetic control (Scheme 5). Transition states TS-N7 Cym and TS-N9 $_{\text {Cym }}$ are very similar to the structures of TS-N7Fc and TS-N9Fe, except the adjacent organometallic parts are different (Figure 4). The reaction follows the mechanism described for the ferrocene system, i.e. the adenine anion reacts with the acryloylcymantrene in a one-step process in which the N-C bond is formed simultaneously with enolization of the acryloyl system.

For the reaction of acryloylcymantrene with the adenine anion, the calculated barriers are 10$14 \mathrm{~kJ} / \mathrm{mol}$ lower in energy than the barriers for the respective processes in acryloylferrocene. This suggests that acryloylcymantrene is more reactive as a Michael acceptor and hence the kinetic control of the addition reactions is less important. At $75^{\circ} \mathrm{C}$, the two energy barriers (ca. $90 \mathrm{~kJ} / \mathrm{mol}$ ) are both surmountable. Under the experimental conditions employed, the thermodynamic reaction control prevails and the more stable isomer $\mathbf{5}$ is formed as the main product. Additional support for the higher reactivity of acryloylcymantrene comes from the frontier molecular orbital analysis (Figure S19). The calculated energy gap between the HOMO (adenine as a nucleophile) and the LUMO (Michael acceptor) is smaller for the acryloylcymantrene. This suggests that the reaction between adenine and acryloylcymantrene should be faster than the corresponding reaction with acryloylferrocene.

\section{Electrochemistry}

The electrochemical measurements of $1,3,5,9,11$ and 15 were carried out under an atmosphere of argon in anhydrous dichloromethane $(\mathbf{1}, \mathbf{3}, \mathbf{5}, \mathbf{9}, \mathbf{1 1}, \mathbf{1 5})$, tetrahydrofuran (5) and acetonitrile (5) solutions, containing weakly coordinating $[\mathrm{Bu} 4 \mathrm{~N}]\left[\mathrm{B}\left(\mathrm{C}_{6} \mathrm{~F}_{5}\right)_{4}\right]^{[21]}(0.1 \mathrm{M})$ as the supporting electrolyte. The cyclic voltammetry measurements were recorded at scan rates varying between $50 \mathrm{mV} \cdot \mathrm{s}^{-1}$ and $200 \mathrm{mV} \cdot \mathrm{s}^{-1}$. All redox potentials are referenced against the $\mathrm{FcH} / \mathrm{FcH}^{+}$redox couple $\left(E^{\circ \prime}=0.00 \mathrm{~V}\right)$ as recommended by IUPAC $\left(\mathrm{FcH}=\mathrm{Fe}\left(\eta^{5} \mathrm{C}_{5} \mathrm{H}_{5}\right)_{2}\right){ }^{[22]}$ The benefit of using $\left[\mathrm{B}\left(\mathrm{C}_{6} \mathrm{~F}_{5}\right)_{4}\right]^{-}$for the generation of cymantrene-based cationic oxidation products was recently reported. ${ }^{[23,24]}$ Table 1 summarizes the respective electrochemical data. 
The corresponding cyclic voltammograms (= CV) for $\mathbf{1}, \mathbf{3}, \mathbf{5}, \mathbf{9}, \mathbf{1 1}$ and 15 are shown in Figures 5 and S19-S22 (ESI).

Table 1. Voltammetric data for compounds $1,3, \mathbf{5}, \mathbf{9}, \mathbf{1 1}$ and $15 .^{a}$

\begin{tabular}{cccc}
\hline Compound & $E_{\mathrm{pa}}[\mathrm{mV}]^{b}$ & $E_{\mathrm{pc}}[\mathrm{mV}]^{c}$ & $i_{p c} / i_{p a}$ \\
\hline $\mathbf{1}$ & 1195 & - & - \\
$\mathbf{3}$ & 1180 & - & - \\
$\mathbf{5}$ & 975 & - & - \\
$\mathbf{9}$ & $365^{d}$ & $305^{d}$ & 0.92 \\
& 1415 & - & - \\
$\mathbf{1 1}$ & 910 & 820 & 0.58 \\
$\mathbf{1 5}$ & 855 & - & - \\
& 975 & 905 & 0.41
\end{tabular}

${ }^{a}$ Potentials vs $\mathrm{FcH} / \mathrm{FcH}^{+}$; scan rate $100 \mathrm{mV} \cdot \mathrm{s}^{-1}$; glassy-carbon electrode of $1.0 \mathrm{mmol} \cdot \mathrm{L}^{-1}$ solutions of the analytes in anhydrous dichloromethane containing $0.1 \mathrm{~mol} \cdot \mathrm{L}^{-1}$ of $\left[\mathrm{N}^{n} \mathrm{Bu}_{4}\right]\left[\mathrm{B}\left(\mathrm{C}_{6} \mathrm{~F}_{5}\right)_{4}\right]$ as supporting electrolyte at $25{ }^{\circ} \mathrm{C} .{ }^{b} E_{\mathrm{pc}}=$ cathodic peak potential. ${ }^{c} E_{\mathrm{pa}}=$ anodic peak potential. ${ }^{d}$ Formal Potential $E^{\circ \prime}=335 \mathrm{mV}$.

Compounds 1, 3, 5, 9, 11 and 15 exhibit diffusion controlled anodic oxidations, except 9 which shows an almost reversible process at $335 \mathrm{mV}\left(i_{\mathrm{pc}} / i_{\mathrm{pa}}=0.91\right)$ and an irreversible second oxidation at $1415 \mathrm{mV}$. Exemplary, the influence of the solvent on the oxidation process of the cymantrene compounds was studied using thymine derivative 5. It was found that in tetrahydrofuran and acetonitrile, respectively, irreversible electrode reactions took place (Figure S19). In acetonitrile, additional follow-up reactions of mono-oxidized $\mathbf{5}^{+}$were observed, most probably attributed to a substitution of one carbonyl ligand by a solvent molecule. ${ }^{[24]}$ However, changing the solvent to less nucleophilic dichloromethane resulted in a 
more stable current and an irreversible event was observed for 5 at $E_{\mathrm{pa}}=975 \mathrm{mV}$ (Figure 5). Also for the adenine derivative 3 only one irreversible oxidation process at $E_{\mathrm{pa}}=1180 \mathrm{mV}$ was observed in dichloromethane solution (Figure 5). The higher redox potential of $\mathbf{3}$, as compared to $\mathbf{5}$, substantiates higher electron withdrawing ability of the thymine group in comparison to the adenine one. However, for both compounds a rapid filming of the working electrode was observed after several cycles. Cymantrene alcohols $\mathbf{1 1}$ and $\mathbf{1 5}$ show a different redox behavior in comparison to $\mathbf{3}$ and $\mathbf{5}$. For $\mathbf{1 1}$ there is one oxidation process found at $E_{\mathrm{pa}}=$ $910 \mathrm{mV}$ and one reduction event at $E_{\mathrm{pc}}=820 \mathrm{mV}$ while for $\mathbf{1 5}$ two oxidations at $E_{\mathrm{pa}}=855$ $\mathrm{mV}$ and $E_{\mathrm{pa}}=975 \mathrm{mV}$ and one reduction at $E_{\mathrm{pc}}=905 \mathrm{mV}$ (Figure 5) are present. The second oxidation process is presumably due to oxidation of side products generated upon the first oxidation. The latter electrode reactions are shifted to more cathodic potentials, when compared to $\mathbf{3}$ and $\mathbf{5}$, due to a less electron-withdrawing of the hydroxyl functionality in $\alpha$ position. Furthermore, the trend that the thymine substituent shifts the redox process to more cathodic potentials is also typical for these species. As reported by Geiger et al., the cymantrene mono-cations become more stable against substitution of one carbonyl ligand as the electronic-donating character of the cyclopentadienyl ligand increases. ${ }^{[24]}$ This is the reason why 11 and 15 shows a reduction process and 3 and 5 not. Exemplary, CV measurements at lower temperatures $\left(0{ }^{\circ} \mathrm{C},-20^{\circ} \mathrm{C}\right)$ were performed for 15 , but no increase of reversibility was observed. 


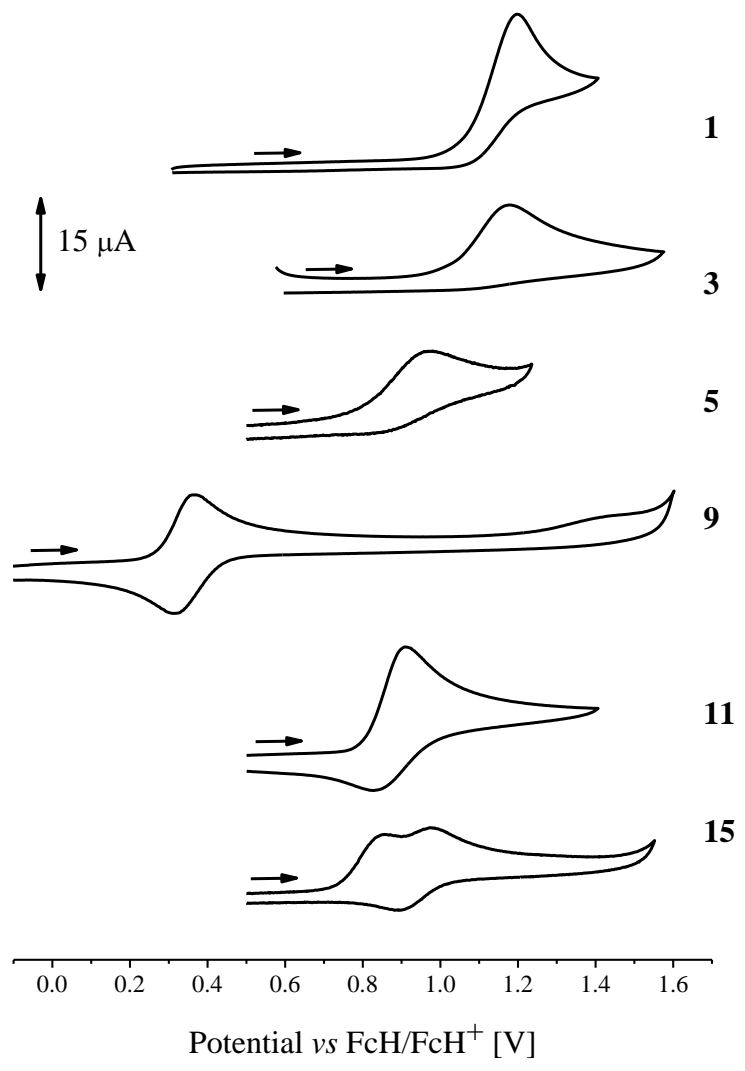

Figure 5 Cyclic voltammograms of 1, 3, 5, 9, 11 and $15\left(1.0 \mathrm{mmol} \cdot \mathrm{L}^{-1}\right)$, scan rate $100 \mathrm{mV} \cdot \mathrm{s}^{-1}$ at $25{ }^{\circ} \mathrm{C}$, supporting electrolyte $0.1 \mathrm{~mol} \cdot \mathrm{L}^{-1}[\mathrm{Bu} 4 \mathrm{~N}]\left[\mathrm{B}\left(\mathrm{C}_{6} \mathrm{~F}_{5}\right)_{4}\right]$, working electrode: glassy carbon electrode (surface area $0.031 \mathrm{~cm}^{2}$ ).

To gain more information on the redox-process of the molecule pattern, electrochemical measurements on $\mathbf{1}$ were performed, showing a similar behavior as $\mathbf{3}$ and $\mathbf{5}$, i.e. one irreversible oxidation process at $E_{\mathrm{pa}}=1195 \mathrm{mV}$ (Figure 5). For investigating of the influence of nucleobases on the redox behavior and the deposition process, adenine was added ( $1 \mathrm{mmol}$ $\mathrm{L}^{-1}$ ) to the analyte solution. The oxidation peak current $i_{\mathrm{pa}}$ dropped with the numbers of cycles, thus the mixture of $\mathbf{3}$ and adenine behaved similar to compound $\mathbf{5}$ (Figure S20) in the electrochemical measurements. For further investigation on the substitution of carbonyl 
ligands in the cymantrene molecule pattern, CV measurements on 9 were performed (Figure $\mathrm{S} 21)$. A reversible redox process $\left(E^{\circ \prime}=335 \mathrm{mV}\right)$ and an irreversible oxidation event $\left(E_{\mathrm{pa}}=\right.$ $1415 \mathrm{mV}$ ) were observed. The irreversible oxidation process disappears after the first cycle, leading to a coating of the working electrode. However, the process associated with the ferrocenyl group is constant over several cycles.

The CV measurements show that the cymantryl ketone cations $\mathbf{1}^{+}, \mathbf{3}^{+}$and $\mathbf{5}^{+}$are unstable in solution. For the cymantryl aldehyde cation this behavior was reported before, indicating a fast carbonyl substitution with a nucleophile. ${ }^{[24]}$ For $\mathbf{3}^{+}$and $\mathbf{5}^{+}$the adeninyl or uracilyl functionalities themselves could react as a nucleophile and undergo some intramolecular or intermolecular side reactions. The lower electron density at the metal, due to a lower electron donation capability of the cyclopentadienyl ligand, promotes the side reactions. ${ }^{[24]}$ For $\mathbf{1 1}$ and 15 a reduction process was found (Figure 5). A higher electron density at the metal (as compared to the cymantryl ketones) increases the metal ligand backbonding towards the carbonyl ligands and hence a slower substitution processes takes place. ${ }^{[24]}$ The shift of the potential of both oxidation processes towards more cathodic potentials is a result of the higher electron density at $\mathrm{Mn}$ for $\mathbf{1 1}^{+}$and $\mathbf{1 5}^{+}$. Therefore, it is possible, at least partially, to reduce the cymantryl alcohol cation. The uracil functionality possesses a less pronounced electron donation character, as compared with the adenine unit, and hence the oxidation processes are cathodic shifted for the corresponding ketones and alcohols, respectively.

\section{Bioactivity}

\section{Antitrypanosomal and cytotoxic activity}

As cymantrene-triazole compounds have been previously shown to inhibit the growth of T. brucei ${ }^{[16 \mathrm{e}]}$, we were interested whether the newly synthesised cymantrene and cyrhetrene nucleobase conjugates were also effective against this protozoan parasite. The trypanocidal 
and cytotoxic activities of the cymantrene and cyrhetrene compounds were evaluated in vitro with $T$. brucei bloodstream forms $427-221 \mathrm{a}^{[25]}$ and human myeloid leukaemia HL-60 cells ${ }^{[26]}$ using the resazurin assay described previously. ${ }^{[27]}$ Apart from compounds 13 and 14, all cymantrene and cyrhetrene nucleobase conjugates showed a dose-dependent effect on the growth of trypanosomes with MIC (minimum inhibitory concentration, i.e., the concentration of the compounds at which all cells were killed) values varying between 10 and $>100 \mu \mathrm{M}$ and $\mathrm{GI}_{50}(50 \%$ growth inhibition, i.e., the concentration of a compound necessary to reduce the growth rate of cells by $50 \%$ to that of controls) values ranging from 0.38 to $80.5 \mu \mathrm{M}$ (Table 2).

Table 2. The in vitro antitrypanosomal and cytotoxic activity of cymantrene, cyrhetrene, suramin and compounds 1-16 against $T$. brucei and human myeloid leukaemia HL-60 cells.

\begin{tabular}{|c|c|c|c|c|c|c|}
\hline \multirow[b]{2}{*}{ Compound. } & \multicolumn{2}{|l|}{ T. brucei } & \multicolumn{2}{|l|}{ HL-60 } & \multicolumn{2}{|c|}{ Selectivity } \\
\hline & $\mathrm{MIC}(\mu \mathrm{M})$ & $\mathrm{Gl}_{50}(\mu \mathrm{M})^{\mathrm{a}}$ & $\mathrm{MIC}(\mu \mathrm{M})$ & $\mathrm{Gl}_{50}(\mu \mathrm{M})^{\mathrm{a}}$ & $\begin{array}{l}\text { MIC } \\
\text { ratio }\end{array}$ & $\begin{array}{l}\mathrm{Gl}_{50} \\
\text { ratio }\end{array}$ \\
\hline Cym & 100 & $44.6 \pm 12.3$ & $>100$ & $>100(0 \%)$ & $>1$ & $>2.2$ \\
\hline Cyr & $>100$ & >100 (9\%) & $>100$ & $>100(3 \%)$ & 1 & 1 \\
\hline 1 & 10 & $0.38 \pm 0.01$ & 100 & $29.6 \pm 10.1$ & 10 & 77.9 \\
\hline 2 & 10 & $2.73 \pm 0.04$ & 100 & $29.6 \pm 2.6$ & 10 & 10.8 \\
\hline 3 & 10 & $4.41 \pm 1.02$ & $>100$ & $>100(3 \%)$ & $>10$ & $>22.7$ \\
\hline 4 & 100 & $3.60 \pm 0.66$ & $>100$ & $>100(22 \%)$ & $>1$ & $>27.8$ \\
\hline 5 & $>100$ & $59.6 \pm 11.1$ & $>100$ & $>100(6 \%)$ & 1 & $>1.7$ \\
\hline 6 & 10 & $3.36 \pm 0.39$ & $>100$ & $>100(0 \%)$ & $>10$ & $>29.8$ \\
\hline 7 & 10 & $3.55 \pm 0.13$ & $>100$ & $>100(0 \%)$ & $>10$ & $>28.2$ \\
\hline 9 & 100 & $18.2 \pm 5.5$ & $>100$ & $>100(12 \%)$ & $>1$ & $>5.5$ \\
\hline 10 & 100 & $20.5 \pm 5.3$ & $>100$ & $>100(0 \%)$ & $>1$ & $>4.9$ \\
\hline 11 & 100 & $38.8 \pm 8.9$ & $>100$ & >100 (3\%) & $>1$ & $>2.6$ \\
\hline 12 & $>100$ & $80.5 \pm 24.7$ & $>100$ & >100 (0\%) & 1 & $>1.2$ \\
\hline 13 & $>100$ & $>100$ (33\%) & $>100$ & $>100(0 \%)$ & 1 & 1 \\
\hline 14 & $>100$ & $>100$ (19\%) & $>100$ & $>100(0 \%)$ & 1 & 1 \\
\hline 15 & $>100$ & $30.8 \pm 3.5$ & $>100$ & $>100(2 \%)$ & 1 & $>3.2$ \\
\hline 16 & 10 & $1.67 \pm 0.37$ & 100 & $21.8 \pm 8.6$ & 10 & 13.1 \\
\hline Suramin & $0.1-1$ & $0.039 \pm 0.003$ & $>100$ & $>100(4 \%)$ & $\begin{array}{l}>1000- \\
100\end{array}$ & $>2564$ \\
\hline
\end{tabular}

${ }^{a}$ Values in brackets are the growth inhibition at $100 \mu \mathrm{M}$. 
In most cases, the nucleobase conjugates were more active than the parent compounds cymantrene and cyrhetrene. The thymine and uracil conjugates $3,4,6$ and 7 displayed similar trypanocidal activity with $\mathrm{GI}_{50}$ values of around $4 \mu \mathrm{M}$, while their corresponding alcohols $\mathbf{1 1}$, 12, 13 and 14 were much less active. Cymantrene and ferrocene adenine conjugates 5, 15, 9, and $\mathbf{1 0}$ were also less effective. Interestingly, the chloropropionyl compounds $\mathbf{1}$ and $\mathbf{2}$ used in the synthesis of cymantrene and cyrhetrene nucleobase conjugates exhibited higher trypanocidal activity, which is probably due to their alkylating reactivity. Notably, replacement of the chlorine atom in $\mathbf{1}$ and $\mathbf{2}$ by nucleobases resulted in compounds with no cytotoxicity against human cells, while their trypanocidal activity of their thymine and uracil conjugates was reduced 1.3-fold (cyrhetrene conjugates 6 and 7) and 10-fold (cymantrene conjugates 3 and 4), respectively. Also the cymantrene-dppe derivative $\mathbf{1 6}$ showed increased antitrypanosomal activity. With the exception of 1, 2 and 16, all other compounds were nontoxic to HL-60 cells (Table 2). This is an important finding as one crucial criteria for the development of new trypanocidal drugs is the absence of toxicity to mammalian cells. Despite the lack of cytotoxicity of cymantrene and cyrhetrene nucleobase conjugates, their MIC and $\mathrm{GI}_{50}$ ratios of cytotoxic to trypanocidal activities (selectivity indices) were found to be in an unfavourable to modest range (Table 2). For comparison, the reference drug suramin, one of the drugs used in the treatment of sleeping sickness, had a MIC ratio and a GI50 ratio of $>1000-100$ and >2000, respectively (Table 2). Nevertheless, cymantrene and cyrhetrene nucleobase conjugates are promising trypanocidal compounds that provide templates for further optimization to increase their antitrypanosomal activity.

\section{Conclusions}

Eleven cymantrene- and cyrhetrene-nucleobase conjugates have been synthesized and characterized. They represent the first examples of functionalized nucleobase cymantrene and cyrhetrene compounds. Furthermore, the synthesis of a hitherto unreported $N 7$-isomer of a ferrocene-adenine conjugate is reported. The key step in synthesis of all compounds involved 
an N1-regioselective Michael addition of the respective nucleobase nucleophile (a Michael donor) to an in situ generated organometallic acryloyl electrophile reagent (a Michael acceptor). The Michael addition reaction of acryloylferrocene with adenine afforded the N9adenine isomer along with the $N 7$-isomer. In contrary, when acryloylcymantrene was reacted with adenine only the respective $N 9$-adenine isomer was formed. DFT calculations show that the reaction of acryloylferrocene with adenine is kinetically controlled, while acryloylcymantrene reacts with adenine under thermodynamic control. A single crystal X-ray diffraction study of $\mathbf{5}$ revealed that the cymantrenyl moiety binds to the N9-position of the adenine nucleobase and that the plane of the adenine and the cyclopentadienyl group are almost perpendicular to each other. Electrochemical measurements on the cymantrenyl nucleobases showed irreversible behavior for all compounds presumably associated with a ligand exchange of carbonyls with the donor functionality of the nucleobases. These processes also caused a deposition at the electrode surface.

The in vitro antitrypanosomal activity assay showed that cymantrene and cyrhetrene ketone nucleobases were more active than their corresponding alcohol derivatives. The substitution of the chlorine atom by nucleobase moieties in chloroketone cymantrene and cyrhetrene retain antitrypanosomal activity but eliminate undesired cytotoxic effect towards human cells. Substitution of two CO ligands in the cymantrene framework by the phosphine ligand 1,2-bis(diphenylphosphino)ethane led to an increase in antitrypanosomal activity. This, however, was associated with an increase in cytotoxic activity. The compounds synthesized in this study are amongst the most potent antitrypanosomal organometallics described to date. Further effort is undertaken in our lab to obtain more active derivatives.

\section{Experimental}

\section{General:}


All preparations were carried out using standard Schlenk techniques. Chromatographic separations were carried out using silica gel 60 (Merck, 230-400 mesh ASTM) and aluminium oxide (EcoChrom ${ }^{\mathrm{TM}}$ MP Biomedicals). Dichloromethane, trimethylamine, dimethylformamide, and tetrahydrofuran were distilled and deoxygenated prior to use. Other solvents were of reagent grade and were used without prior purification. Thymine, uracil, adenine, 3chloropropionyl chloride, lithium aluminum hydride, sodium borohydride, aluminium chloride, and 1,2-bis(diphenylphosphino)ethane were purchased from commercial suppliers and were used without further purification. ${ }^{1} \mathrm{H}$ NMR $(600 \mathrm{MHz})$ and ${ }^{13} \mathrm{C}\{\mathrm{H}\}$ NMR (150 MHz) spectra were recorded with a Bruker Avance III 600 spectrometer operating at $298 \mathrm{~K}$ in the Fourier transform mode. Chemical shifts are reported in $\delta$ units (ppm) using residual DMSO $\left({ }^{1} \mathrm{H} \delta 2.50 \mathrm{ppm},{ }^{13} \mathrm{C} \delta 39.70\right)$ as reference. Infrared spectra were recorded with an FTIR Nexus Nicolet apparatus. Mass spectra were recorded with a Varian 500-MS iT mass spectrometer (ESI) or with a Finnigan Mat95 mass spectrometer (EI). Microanalyses were determined by Analytical Services of the Polish Academy of the Sciences, Łódź. Purification of compound 16 was achieved by normal phase HPLC (Shimadzu Prominence with LC-20AP pumps) with Luna 5u Silica (2) 100A, AXIA Packed 150 X $21.1 \mathrm{~mm}$ preparative column.

\section{DFT and TD-DFT computations}

The quantum chemical calculations were performed using the Gaussian09 suite of programs. ${ }^{[28]}$ All geometries were fully optimized at the B3LYP/6-31+G(d) level ${ }^{[29]}$ in the gas phase and in the model solvent (DMF). The latter results are presented throughout the text (full details are listed in Table S4). The solvent effects on geometry optimization and solvation free energies $\left(\Delta \mathrm{G}_{\text {solv }}\right)$ have been determined using the self-consistent reaction field (SCRF) method based on the polarizable conductor calculation model $(\mathrm{CPCM}) .{ }^{[30]}$ The solvent relative permittivity of $\varepsilon=37.219$ (DMF) and electrostatic scaling ( $\alpha$ ) of 1.2 were 
used. The united atom topological model (UA0) was applied on atomic radii of the UFF force field for heavy atoms. All energies are reported at $343.15 \mathrm{~K}$ in order to reproduce the experimental conditions. Thermal corrections to Gibbs free energies were calculated at the B3LYP/6-31+G(d) level using the rigid rotor/harmonic oscillator model, and were scaled by 0.9806. ${ }^{[31]}$ Analytical vibrational analyses at the corresponding level of theory were performed to characterize each stationary point as minimum $($ NImag $=0)$ or first-order saddle point $($ NImag $=1)$. Intrinsic reaction coordinate $($ IRC) calculations were performed at the corresponding level to identify the minima connected through the transition state. Improved energetics were calculated using B3LYP method with the augmented Wachters' basis set on Fe and $\mathrm{Mn},{ }^{[32]}$ and $6-311+\mathrm{G}(\mathrm{d}, \mathrm{p})$ basis set on all other atoms.

\section{Electrochemistry}

Electrochemical measurements on dichloromethane solutions containing $1.0 \mathrm{mmol} \cdot \mathrm{L}^{-1}$ of $\mathbf{1}$, 3, 5, 9, 11 or 15 were performed at $25{ }^{\circ} \mathrm{C}$ with a Radiometer Voltalab PGZ 100 electrochemical workstation interfaced with a personal computer. Dichloromethane solutions $\left(0.1 \mathrm{~mol} \cdot \mathrm{L}^{-1}\right)$ containing $\left[\mathrm{NBu}_{4}\right]\left[\mathrm{B}\left(\mathrm{C}_{6} \mathrm{~F}_{5}\right)_{4}\right]^{[21]}$ were used as supporting electrolyte. For the measurements a three electrode cell containing a Pt auxiliary electrode, a glassy carbon working electrode (surface area $\left.0.031 \mathrm{~cm}^{2}\right)$ and an $\mathrm{Ag} / \mathrm{Ag}^{+}\left(0.01 \mathrm{mmol} \cdot \mathrm{L}^{-1}\left[\mathrm{AgNO}_{3}\right]\right)$ reference electrode fixed on a Luggin capillary was applied. The working electrode was pretreated by polishing on a Buehler microcloth first with a 1 micron and then with a $1 / 4$ micron diamond paste. The reference electrode was constructed from a silver wire inserted into a $0.01 \mathrm{mmol} \cdot \mathrm{L}^{-1} \quad \mathrm{AgNO}_{3}$ and $0.1 \mathrm{~mol} \cdot \mathrm{L}^{-1}\left[\mathrm{NBu}_{4}\right]\left[\mathrm{B}\left(\mathrm{C}_{6} \mathrm{~F}_{5}\right)_{4}\right]$ acetonitrile solution in a Luggin capillary with a Vycor tip. This Luggin capillary was inserted into a second Luggin capillary containing a $0.1 \mathrm{~mol} \cdot \mathrm{L}^{-1}\left[\mathrm{NBu}_{4}\right]\left[\mathrm{B}\left(\mathrm{C}_{6} \mathrm{~F}_{5}\right)_{4}\right]$ dichloromethane solution and a Vycor tip. Experiments under the same conditions showed that all reduction and oxidation potentials 
were reproducible within $5 \mathrm{mV}$. Experimental potentials were referenced against an $\mathrm{Ag} / \mathrm{Ag}^{+}$ reference electrode but the presented results are referenced against ferrocene as an internal standard as required by IUPAC. ${ }^{[22]}$ To achieve this, each experiment was repeated in the presence of $1 \mathrm{mmol} \cdot \mathrm{L}^{-1}$ decamethylferrocene $\left(=\mathrm{Fc}^{*}\right)$. Data were processed on a Microsoft Excel worksheet to set the formal reduction potentials of the $\mathrm{FcH} / \mathrm{FcH}^{+}$couple to $0.0 \mathrm{~V}$. Under our conditions the $\mathrm{Fc}^{*} / \mathrm{Fc}^{*+}$ couple was at $-619 \mathrm{mV}$ vs $\mathrm{FcH} / \mathrm{FcH}^{+}\left(\Delta E_{\mathrm{p}}=60 \mathrm{mV}\right)$, while the $\mathrm{FcH} / \mathrm{FcH}^{+}$couple itself was at $220 \mathrm{mV} v s \mathrm{Ag} / \mathrm{Ag}^{+}\left(\Delta E_{\mathrm{p}}=61 \mathrm{mV}\right) .{ }^{[33]}$

\section{Antitrypanosomal and cytotoxicity assays}

Bloodstream forms of T. brucei clone $427-221 \mathrm{a}^{[25]}$ and human myeloid leukaemia HL-60 cells $^{[26]}$ were grown in Baltz medium ${ }^{[34]}$ and RPMI medium ${ }^{[35]}$, respectively. Both media were supplemented with $16.7 \%$ heat-inactivated foetal calf serum. All cultures were maintained at $37{ }^{\circ} \mathrm{C}$ in a humidified atmosphere containing $5 \%$ of $\mathrm{CO}_{2}$. Toxicity assays were performed as previously described. ${ }^{[27]}$ In brief, trypanosomes and HL-60 cells were seeded at an initial cell density of $10^{4} \mathrm{~mL}^{-1}$ and $10^{5} \mathrm{~mL}^{-1}$, respectively, in 96-well plates in a final volume of $200 \mu \mathrm{L}$ culture medium containing various concentrations of test compounds dissolved in $100 \%$ DMSO. It should be noted that none of the test compounds formed precipitates when diluted with medium. The controls contained DMSO alone. In all experiments, the final DMSO concentration was $0.9 \%$. After $24 \mathrm{~h}$ incubation, $20 \mu \mathrm{l}$ of a $0.44 \mathrm{mM}$ resazurin solution prepared in PBS was added and the cultures were incubated for a further $48 \mathrm{~h}$. Resazurin is a vital dye that, when being reduced by living cells, changes its colour from blue to pink. Thus, by measuring absorbance, the proliferation of cells can be easily determined. The change in absorbance was read on a microplate reader using a test wavelength of $570 \mathrm{~nm}$ and a reference wavelength of $630 \mathrm{~nm}$. GI50 values were calculated by linear interpolation according to the method described by Huber and Koella. ${ }^{[36]}$ MIC values were determined microscopically.

\section{Synthesis of chloropropionyl-cymantrene (1)}


Cymantrene (500 mg, $2.45 \mathrm{mmol})$ dissolved in dichloromethane $(25 \mathrm{~mL})$ was treated with 3-chloropropionyl chloride ( $234 \mu \mathrm{L}, 2.45 \mathrm{mmol})$ and $\mathrm{AlCl}_{3}(327 \mathrm{mg}, 2.45 \mathrm{mmol})$. After $5 \mathrm{~h}$ at ambient temperature, the reaction mixture was poured onto a $3 \%$ aqueous $\mathrm{HCl}$ solution. The resulting dichloromethane and water phases were separated. The dichloromethane phase was dried over $\mathrm{MgSO}_{4}$ and evaporated to dryness. The residue was dissolved in dichloromethane and subjected to column chromatography on $\mathrm{SiO}_{2}$ (eluent dichloromethane) to give compound $\mathbf{1}$ as a yellow solid. Crystallization from dichloromethane- $n$-pentane at $-78{ }^{\circ} \mathrm{C}$ afforded $\mathbf{1}$ as yellow crystals in a yield of $88 \%(635 \mathrm{mg})$.

${ }^{1} \mathrm{H}$ NMR $\left(600 \mathrm{MHz}, \mathrm{DMSO}-\mathrm{d}_{6}\right): \delta=5.85\left(\mathrm{pt}, J_{\mathrm{H}, \mathrm{H}}=1.8 \mathrm{~Hz}, 2 \mathrm{H}, \mathrm{Cp}\right), 5.21\left(\mathrm{pt}, J_{\mathrm{H}, \mathrm{H}}=1.8 \mathrm{~Hz}\right.$, $2 \mathrm{H}, \mathrm{Cp}), 3.84\left(\mathrm{t}, J_{\mathrm{H}, \mathrm{H}}=6.0 \mathrm{~Hz}, 2 \mathrm{H}, \mathrm{CH}_{2}\right), 3.16\left(\mathrm{t}, J_{\mathrm{H}, \mathrm{H}}=6.0 \mathrm{~Hz}, 2 \mathrm{H}, \mathrm{CH}_{2}\right) .{ }^{13} \mathrm{C} \mathrm{NMR}(150$ MHz, DMSO-d 6 ): $\delta=223.5,194.3,91.7,87.9,85.2,41.0,38.9$. MS (EI, 70eV): $\mathrm{m} / \mathrm{z}=$ 294( $\left.\mathrm{M}^{+}\right), 238\left(\mathrm{M}^{+}-2 \mathrm{CO}\right), 210\left(\mathrm{M}^{+}-3 \mathrm{CO}\right)$. FTIR (KBr): 3129(CH), 3107(CH), 2987(CH), 2968(CH), 2908(CH), 2027(CO), 1945(CO), 1926(CO), 1679(C=O), 1461, 1397, 1382, 1264 $\mathrm{cm}^{-1}$. Anal. Calcd for $\mathrm{C}_{11} \mathrm{H}_{8} \mathrm{O}_{4} \mathrm{ClMn}: \mathrm{C}, 44.85 ; \mathrm{H}, 2.74 \%$. Found: C, 44.90; H, $2.59 \%$.

\section{Synthesis of chloropropionyl-cyrhetrene (2)}

Cyrhetrene (215 mg, $0.6 \mathrm{mmol})$ dissolved in dichloromethane $(15 \mathrm{~mL})$ was treated with 3chloropropionyl chloride $(122 \mu \mathrm{L}, 1.28 \mathrm{mmol})$ and $\mathrm{AlCl}_{3}(85 \mathrm{mg}, 0.6 \mathrm{mmol})$. After $4 \mathrm{~h}$ of stirring at ambient temperature, the reaction mixture was poured onto a $3 \%$ aqueous $\mathrm{HCl}$ solution. The resulting dichloromethane and water phases were separated. The dichloromethane phase was dried over $\mathrm{MgSO}_{4}$ and evaporated to dryness. The residue was dissolved in chloroform and subjected to column chromatography on $\mathrm{SiO}_{2}$ (eluent chloroform) to give chloropropionyl-cyrhetrene $\mathbf{2}$ as a colourless solid. Crystallization from chloroform- $n$-pentane afforded the compound as colourless crystals in $76 \%$ yield $(425 \mathrm{mg}$ ). 
${ }^{1} \mathrm{H}$ NMR (600 MHz, DMSO-d 6 ): $\delta=6.46\left(\mathrm{pt}, J_{\mathrm{H}, \mathrm{H}}=2.3 \mathrm{~Hz}, 2 \mathrm{H}, \mathrm{Cp}\right), 5.80\left(\mathrm{pt}, J_{\mathrm{H}, \mathrm{H}}=2.3 \mathrm{~Hz}\right.$, $2 \mathrm{H}, \mathrm{Cp}), 3.84\left(\mathrm{t}, J_{\mathrm{H}, \mathrm{H}}=6.0 \mathrm{~Hz}, 2 \mathrm{H}, \mathrm{CH}_{2}\right), 3.16\left(\mathrm{t}, J_{\mathrm{H}, \mathrm{H}}=6.0 \mathrm{~Hz}, 2 \mathrm{H}, \mathrm{CH}_{2}\right) .{ }^{13} \mathrm{C} \mathrm{NMR}(150$ MHz, DMSO-d 6 ): $\delta=193.1,192.2,96.2,89.6,87.2,40.8,39.1 . \mathrm{MS}(\mathrm{ESI}): \mathrm{m} / \mathrm{z}=427\left(\mathrm{M}^{+} \mathrm{H}^{+}\right)$. FTIR (KBr): 3142(CH), 3120(CH), 3110(CH), 2956(CH), 2898(CH), 2034(CO), 1936(CO), 1913(CO), 1676(C=O), 1461, $1369 \mathrm{~cm}^{-1}$. Anal. Calcd for $\mathrm{C}_{11} \mathrm{H}_{8} \mathrm{O}_{4} \mathrm{ClRe}$ C, 31.03; H, $1.89 \%$ Found: C, 30.96; H, $1.83 \%$.

\section{General procedure for the synthesis of cymantrene and cyrhetrene Michael adducts 3-7}

To a stirred solution of the appropriate chloropropionyl-cymantrene $(1.0 \mathrm{mmol})$ in DMF $(15 \mathrm{~mL})$ at ambient temperature $280 \mu \mathrm{L}(2.0 \mathrm{mmol})$ of trimethylamine were added in a single portion. After stirring the reaction solution for $20 \mathrm{~min}$, the appropriate nucleobase $(1.0 \mathrm{mmol})$ was added and the mixture was stirred at a temperature of $75{ }^{\circ} \mathrm{C}$ for $5 \mathrm{~h}$. Subsequently, the solvent was evaporated and the residue subjected to column chromatography on $\mathrm{SiO}_{2}$. Chromatographically purified complexes 3-7 were crystallized to yield analytically pure products.

Compound 3 Chromatography eluent: chloroform-methanol, 50/4 (v/v). Crystallization from dichloromethane- $n$-hexane gave 3 as a yellow solid in a yield of $89 \%$ (342 mg).

${ }^{1} \mathrm{H}$ NMR (600 MHz, DMSO-d 6 ): $\delta=11.18$ (s, 1H, NH), 7.47 (s, 1H, H6 thymine), 5.81(pt, $\left.J_{\mathrm{H}, \mathrm{H}}=1.8 \mathrm{~Hz}, 2 \mathrm{H}, \mathrm{Cp}\right), 5.20\left(\mathrm{pt}, J_{\mathrm{H}, \mathrm{H}}=1.8 \mathrm{~Hz}, 2 \mathrm{H}, \mathrm{Cp}\right), 3.90\left(\mathrm{t},{ }^{3} J_{\mathrm{H}, \mathrm{H}}=6.6 \mathrm{~Hz}, 2 \mathrm{H}, \mathrm{CH}_{2}\right)$, $3.05\left(\mathrm{t},{ }^{3} J_{\mathrm{H}, \mathrm{H}}=6.6 \mathrm{~Hz}, 2 \mathrm{H}, \mathrm{CH}_{2}\right), 1.72\left(\mathrm{~s}, 3 \mathrm{H}, \mathrm{CH}_{3}\right) .{ }^{13} \mathrm{C} \mathrm{NMR}\left(150 \mathrm{MHz}, \mathrm{DMSO}-\mathrm{d}_{6}\right): \delta=$ 223.4, 195.7, 164.3, 150.8, 141.8, 108.2, 91.6, 87.6, 85.3, 42.9, 37.5, 11.9. MS (EI, 70eV): $\mathrm{m} / \mathrm{z}=384\left(\mathrm{M}^{+}\right), 300\left(\mathrm{M}^{+}-3 \mathrm{CO}\right)$. FTIR (KBr): 2955(CH), 2925(CH), 2854(CH), 2027(CO), $1939(\mathrm{CO}), 1674(\mathrm{C}=\mathrm{O}) \mathrm{cm}^{-1}$. Anal. Calcd for $\mathrm{C}_{16} \mathrm{H}_{13} \mathrm{~N}_{2} \mathrm{O}_{6} \mathrm{Mn}: \mathrm{C}, 50.02 ; \mathrm{H}, 3.41 ; \mathrm{N}, 7.29 \%$. Found: C, $50.09 ; \mathrm{H}, 3.52 ; \mathrm{N}, 7.08 \%$.

Compound 4 Chromatography eluent: chloroform-methanol, 50/2 (v/v). Crystallization from chloroform- $n$-hexane gave 4 as a yellow solid in a yield of $64 \%$ (240 mg). 
${ }^{1} \mathrm{H}$ NMR $\left(600 \mathrm{MHz}, \mathrm{DMSO}_{\mathrm{d}}\right.$ ) $: \delta=11.18(\mathrm{~s}, 1 \mathrm{H}, \mathrm{NH}), 7.60\left(\mathrm{~d}, J_{\mathrm{H}, \mathrm{H}}=7.8 \mathrm{~Hz}, 1 \mathrm{H}, \mathrm{H} 6\right.$ uracil), $5.80\left(\mathrm{pt}, J_{\mathrm{H}, \mathrm{H}}=1.8 \mathrm{~Hz}, 2 \mathrm{H}, \mathrm{Cp}\right), 5.50\left(\mathrm{~d}, J_{\mathrm{H}, \mathrm{H}}=7.8 \mathrm{~Hz}, 1 \mathrm{H}, \mathrm{H} 5\right.$ uracil), 5.20 (pt, $J_{\mathrm{H}, \mathrm{H}}=$ $1.8 \mathrm{~Hz}, 2 \mathrm{H}, \mathrm{Cp}), 3.93\left(\mathrm{t},{ }^{3} \mathrm{~J}_{\mathrm{H}, \mathrm{H}}=6.6 \mathrm{~Hz}, 2 \mathrm{H}, \mathrm{CH}_{2}\right), 3.05\left(\mathrm{t},{ }^{3} \mathrm{~J}_{\mathrm{H}, \mathrm{H}}=6.6 \mathrm{~Hz}, 2 \mathrm{H}, \mathrm{CH}_{2}\right) .{ }^{13} \mathrm{C}$ NMR (150 MHz, DMSO-d $\left.{ }_{6}\right): \delta=223.3,195.6,163.6,150.7,146.0,100.5,91.5,87.5,85.2$, 43.1, 37.3. (EI, 70eV): $\mathrm{m} / \mathrm{z}=370\left(\mathrm{M}^{+}\right)$, 286(M+3CO). FTIR (KBr): 3101(CH), 3048(CH), 2968(CH), 2933(CH), 2029(CO), 1938(CO), 1676(C=O), 1459,1375, $1264 \mathrm{~cm}^{-1}$. Anal. Calcd for $\mathrm{C}_{15} \mathrm{H}_{11} \mathrm{~N}_{2} \mathrm{O}_{6} \mathrm{Mn}: \mathrm{C}, 48.67 ; \mathrm{H}, 3.00 ; \mathrm{N}, 7.57 \%$. Found: C, $48.95 ; \mathrm{H}, 3.25 ; \mathrm{N}, 7.33 \%$.

Compound 5 Chromatography eluent: chloroform-methanol, 50/4 $(v / v)$. Crystallization from chloroform- $n$-hexane gave $\mathbf{5}$ as a yellow solid in a yield of $60 \%$ (236 mg).

${ }^{1} \mathrm{H}$ NMR (600 MHz, DMSO-d 6 ): $\delta=8.11$ (s, 1H, H2 adenine), 8.04 (s, 1H, H8 adenine), 7.11 $\left(\mathrm{s}, 2 \mathrm{H}, \mathrm{NH}_{2}\right), 5.79\left(\mathrm{pt}, J_{\mathrm{H}, \mathrm{H}}=1.8 \mathrm{~Hz}, 2 \mathrm{H}, \mathrm{Cp}\right), 5.18\left(\mathrm{pt}, J_{\mathrm{H}, \mathrm{H}}=1.8 \mathrm{~Hz}, 2 \mathrm{H}, \mathrm{Cp}\right), 4.42\left(\mathrm{t},{ }^{3} J_{\mathrm{H}, \mathrm{H}}\right.$ $\left.=6.6 \mathrm{~Hz}, 2 \mathrm{H}, \mathrm{CH}_{2}\right), 3.31\left(\mathrm{t},{ }^{3} J_{\mathrm{H}, \mathrm{H}}=6.6 \mathrm{~Hz}, 2 \mathrm{H}, \mathrm{CH}_{2}\right) \cdot{ }^{13} \mathrm{C} \mathrm{NMR}\left(150 \mathrm{MHz}, \mathrm{DMSO}-\mathrm{d}_{6}\right): \delta=$ 223.4, 195.4, 156.0, 152.4, 149.6, 141.2, 119.1, 91.5, 87.6, 85.2, 38.2, 38.0. MS (EI, 70eV): $\mathrm{m} / \mathrm{z}=393\left(\mathrm{M}^{+}\right), 365\left(\mathrm{M}^{+}-\mathrm{CO}\right), 309\left(\mathrm{M}^{+}-2 \mathrm{CO}\right)$. FTIR $(\mathrm{KBr}): 3358(\mathrm{NH}), 3160(\mathrm{NH}), 2933(\mathrm{CH})$, 2021(CO), 1948(CO), 1928(CO), 1675(C=O), 1654(C=O), 1596(NH), 1578(NH) cm ${ }^{-1}$. Anal. Calcd for $\mathrm{C}_{16} \mathrm{H}_{12} \mathrm{~N}_{5} \mathrm{O}_{4} \mathrm{Mn}$ : C, 48.87 ; H, 3.08 ; N, 17.81\%. Found: C, 48.79 ; H, 3.21 ; N, $17.54 \%$.

Compound 6 Chromatography eluent: chloroform-methanol, 50/3 (v/v). Crystallization from chloroform- $n$-pentane gave $\mathbf{6}$ as a colourless solid in a yield of $58 \%(158 \mathrm{mg})$.

${ }^{1} \mathrm{H}$ NMR (600 MHz, DMSO-d 6 ): $\delta=11.18(\mathrm{~s}, 1 \mathrm{H}, \mathrm{NH}), 7.45\left(\mathrm{~d}, J_{\mathrm{H}, \mathrm{H}}=1.08 \mathrm{~Hz}, 1 \mathrm{H}, \mathrm{H} 6\right.$ thymine), $6.43\left(\mathrm{pt}, J_{\mathrm{H}, \mathrm{H}}=2.34 \mathrm{~Hz}, 2 \mathrm{H}, \mathrm{Cp}\right), 5.78\left(\mathrm{pt}, J_{\mathrm{H}, \mathrm{H}}=2.34 \mathrm{~Hz}, 2 \mathrm{H}, \mathrm{Cp}\right), 3.90\left(\mathrm{t},{ }^{3} J_{\mathrm{H}, \mathrm{H}}=\right.$ $\left.6.4 \mathrm{~Hz}, 2 \mathrm{H}, \mathrm{CH}_{2}\right), 3.06\left(\mathrm{t},{ }^{3} J_{\mathrm{H}, \mathrm{H}}=6.4 \mathrm{~Hz}, 2 \mathrm{H}, \mathrm{CH}_{2}\right), 1.72\left(\mathrm{~d}, J_{\mathrm{H}, \mathrm{H}}=0.9 \mathrm{~Hz}, 3 \mathrm{H}, \mathrm{CH}_{3}\right) .{ }^{13} \mathrm{C}$ NMR (150 MHz, DMSO-d 6 ): $\delta=193.5,193.0,164.3,150.8,141.8,108.2,96.1,89.4,87.2$, 43.0, 37.3, 12.0. MS (EI, 70eV): $\mathrm{m} / \mathrm{z}=516\left(\mathrm{M}^{+}\right), 488\left(\mathrm{M}^{+}-\mathrm{CO}\right), 460\left(\mathrm{M}^{+}-2 \mathrm{CO}\right)$. FTIR (KBr): 3149(CH), 3108(CH), 3025(CH), 2930(CH), $2034(\mathrm{CO}), 1933(\mathrm{CO}), 1904(\mathrm{CO}), 1689(\mathrm{C}=\mathrm{O})$, 1673(C=O), 1467, 1457, $1364 \mathrm{~cm}^{-1}$. Anal. Calcd for $\mathrm{C}_{16} \mathrm{H}_{13} \mathrm{~N}_{2} \mathrm{O}_{6} \mathrm{Re}: \mathrm{C}, 37.28 ; \mathrm{H}, 2.54 ; \mathrm{N}$, $5.43 \%$. Found: C, 37.48; H, 2.61; N, 5.42\%. 
Compound 7 Chromatography eluent: chloroform-methanol, 50/2 (v/v). Crystallization from chloroform- $n$-pentane gave 7 as a colourless solid in a yield of 63\% (185 mg).

${ }^{1} \mathrm{H}$ NMR $\left(600 \mathrm{MHz}\right.$, DMSO-d 6 ): $\delta=11.19(\mathrm{bs}, 1 \mathrm{H}, \mathrm{NH}), 7.58\left(\mathrm{~d}, J_{\mathrm{H}, \mathrm{H}}=7.8 \mathrm{~Hz}, 1 \mathrm{H}, \mathrm{H} 6\right.$ uracil), $6.42\left(\mathrm{pt}, J_{\mathrm{H}, \mathrm{H}}=2.2 \mathrm{~Hz}, 2 \mathrm{H}, \mathrm{Cp}\right), 5.79\left(\mathrm{~d}, J_{\mathrm{H}, \mathrm{H}}=2.2 \mathrm{~Hz}, 2 \mathrm{H}, \mathrm{Cp}\right), 5.50\left(\mathrm{dd}, J_{\mathrm{H}, \mathrm{H}}=7.8\right.$ $\mathrm{Hz}, 2.0 \mathrm{~Hz}, 1 \mathrm{H}, \mathrm{H} 5 \mathrm{uracil}), 3.93\left(\mathrm{t},{ }^{3} J_{\mathrm{H}, \mathrm{H}}=6.4 \mathrm{~Hz}, 2 \mathrm{H}, \mathrm{CH}_{2}\right), 3.08\left(\mathrm{t},{ }^{3} J_{\mathrm{H}, \mathrm{H}}=6.4 \mathrm{~Hz}, 2 \mathrm{H}, \mathrm{CH}_{2}\right)$. ${ }^{13} \mathrm{C}$ NMR (150 MHz, DMSO-d 6 ): $\delta=193.5,193.0,163.7,150.9,146.1,100.7,96.1,89.3$, 87.2, 43.3, 37.2. MS (ESI): $\mathrm{m} / \mathrm{z}=525\left(\mathrm{M}+\mathrm{Na}^{+}\right)$. FTIR $(\mathrm{KBr}): 3104(\mathrm{CH}), 3041(\mathrm{CH})$, 2923(CH), 2027(CO), 1915(CO), 1910(CO), 1679(C=O), 1461, $1366 \mathrm{~cm}^{-1}$. Anal. Calcd for $\mathrm{C}_{15} \mathrm{H}_{11} \mathrm{~N}_{2} \mathrm{O}_{6}$ Re: $\mathrm{C}, 35.93 ; \mathrm{H}, 2.21 ; \mathrm{N}, 5.59 \%$ Found: $\mathrm{C}, 35.81 ; \mathrm{H}, 2.37 ; \mathrm{N}, 5.43 \%$.

\section{Synthesis of ferrocenyl Michael adducts 9 and 10}

To a stirred solution of chloropropionyl-ferrocene (1000 mg, $3.6 \mathrm{mmol})$ in DMF (20 mL) trimethylamine $(974 \mu \mathrm{L} 7.0 \mathrm{mmol})$ was added in a single portion at ambient temperature. After $20 \mathrm{~min}$ of stirring, adenine $(487 \mathrm{mg}, 3.6 \mathrm{mmol})$ was added and the mixture was stirred at a temperature of $75{ }^{\circ} \mathrm{C}$ for $4 \mathrm{~h}$. Subsequently, all volatiles were evaporated and the residue subjected to a preliminary column chromatography on $\mathrm{SiO}_{2}$ (eluent chloroform-methanol 50/5 $(v / v))$ which afforded crude $\mathbf{9}$ and $\mathbf{1 0}$, respectively.

Compound 9 was purified by a second column chromatography on deactivated $\mathrm{Al}_{2} \mathrm{O}_{3}$ $\left(\mathrm{Al}_{2} \mathrm{O}_{3} / \mathrm{H}_{2} \mathrm{O} 36 \mathrm{~g} / 1.25 \mathrm{~g}\right)$ using a chloroform-methanol mixture of ratio $50 / 5(\mathrm{v} / \mathrm{v})$ as eluent. After removal of the solvents, compound $\mathbf{9}$ was crystallized from a chloroform- $n$-hexane mixture of ratio $1 / 1(\mathrm{v} / \mathrm{v})$ to afford an analytically pure orange solid sample in a yield of $27 \%$ (365 mg).

Compound 10 was also purified by a second column chromatography on $\mathrm{SiO}_{2}$ with chloroform-methanol 50/5 $(v / v)$ as eluent. Purified 10 was crystallized from a chloroform- $n$ hexane mixture affording $\mathbf{1 0}$ as an orange solid in a $10 \%$ yield $(135 \mathrm{mg})$. 
Compound $9{ }^{1} \mathrm{H}$ NMR $\left(600 \mathrm{MHz}, \mathrm{DMSO}_{\mathrm{d}}\right.$ ): $\delta=8.18$ (s, 1H, H-2 adenine), 8.12 (s, 1H, H8 adenine), $7.13\left(\mathrm{~s}, 2 \mathrm{H}, \mathrm{NH}_{2}\right.$ ), $4.78\left(\mathrm{pt}, J_{\mathrm{H}, \mathrm{H}}=1.8 \mathrm{~Hz}, 2 \mathrm{H}, \mathrm{C}_{5} \mathrm{H}_{4}\right), 4.55\left(\mathrm{pt}, J_{\mathrm{H}, \mathrm{H}}=1.8 \mathrm{~Hz}, 2 \mathrm{H}\right.$, $\left.\mathrm{C}_{5} \mathrm{H}_{4}\right), 4.47\left(\mathrm{t},{ }^{3} J_{\mathrm{HH}}=6.0 \mathrm{~Hz}, 2 \mathrm{H}, \mathrm{CH}_{2}\right), 3.98\left(\mathrm{~s}, 5 \mathrm{H}, \mathrm{C}_{5} \mathrm{H}_{5}\right), 3.39\left(\mathrm{t},{ }^{3} J_{\mathrm{HH}}=6.0 \mathrm{~Hz}, 2 \mathrm{H}, \mathrm{CH}_{2}\right)$. ${ }^{13} \mathrm{C} \mathrm{NMR}\left(150 \mathrm{MHz}, \mathrm{CDCl}_{3}\right): \delta=200.8,156.0,152.4,149.5,141.4,118.9,78.6,72.4,69.5$, 69.1, 38.5, 38.1. MS (EI, 70eV): $\mathrm{m} / \mathrm{z}=375\left(\mathrm{M}^{+}\right)$, 240(acryloyl ferrocene), 135(adenine). FTIR (KBr): 3432, 3270, 3105, 1664(CO), 1603(CO) $\mathrm{cm}^{-1}$. Anal. Calcd for $\mathrm{C}_{18} \mathrm{H}_{17} \mathrm{~N}_{5} \mathrm{OFe}: \mathrm{C}$, 57.62; H, 4.57; N, 18.67\%. Found: C, $57.29 ; \mathrm{H}, 4.46 ; \mathrm{N}, 18.14 \%$.

Compound $10{ }^{1} \mathrm{H}$ NMR (600 MHz, DMSO-d 6 ): $\delta=8.28$ (s, 1H, H-8 adenine), 8.17 (s, 1H, $\mathrm{H}-2$ adenine), 6.99 (s, 2H, NH $\left.\mathrm{N}_{2}\right), 4.739$ (pt, $\left.J_{\mathrm{H}, \mathrm{H}}=1.8 \mathrm{~Hz}, 2 \mathrm{H}, \mathrm{C}_{5} \mathrm{H}_{4}\right), 4.730\left(\mathrm{t},{ }^{3} J_{\mathrm{HH}}=6.0 \mathrm{~Hz}\right.$, $\left.2 \mathrm{H}, \mathrm{CH}_{2}\right), 4.55$ (pt, $\left.J_{\mathrm{H}, \mathrm{H}}=1.8 \mathrm{~Hz}, 2 \mathrm{H}, \mathrm{C}_{5} \mathrm{H}_{4}\right), 3.95\left(\mathrm{~s}, 5 \mathrm{H}, \mathrm{C}_{5} \mathrm{H}_{5}\right), 3.29\left(\mathrm{t},{ }^{3} J_{\mathrm{HH}}=6.0 \mathrm{~Hz}, 2 \mathrm{H}\right.$, $\left.\mathrm{CH}_{2}\right) .{ }^{13} \mathrm{C} \mathrm{NMR}\left(150 \mathrm{MHz}, \mathrm{CDCl}_{3}\right): \delta=200.4,160.2,152.2,151.7,146.6,111.1,78.5,72.4$, 69.5, 69.0, 41.2, 40.4. MS (EI, 70eV): $\mathrm{m} / \mathrm{z}=375\left(\mathrm{M}^{+}\right), 240$ (acryloyl ferrocene), 135(adenine). FTIR (KBr): 3385, 3180, 1648(CO), 1602(CO) $\mathrm{cm}^{-1}$. Anal. Calcd for $\mathrm{C}_{18} \mathrm{H}_{17} \mathrm{~N}_{5} \mathrm{OFe}+n-$ hexane: C, 62.48; H, 6.77; N, 15.18\%. Found: C, 62.19; H, 6.14; N, 15.74\%.

\section{General procedure for the synthesis of cymantrene alcohols 11 and 12}

To a stirred THF solution $(25 \mathrm{~mL})$ containing 3 or $4(0.55 \mathrm{mmol}) \mathrm{Na}\left[\mathrm{BH}_{4}\right](21 \mathrm{mg}, 0.55$ mmol) was added in a single portion at ambient temperature. After 70 min of stirring, the reaction mixture was poured into $25 \mathrm{~mL}$ of water, extracted with chloroform (ca. $40 \mathrm{~mL}$ ), dried over $\mathrm{MgSO}_{4}$ and the obtained solution was evaporated to dryness. The residue was subjected to column chromatography on $\mathrm{SiO}_{2}$ (eluent chloroform-methanol 50/1 $(v / v)$ ). Crystallization from dichloromethane- $n$-hexane gave alcohols $\mathbf{1 1}$ and $\mathbf{1 2}$ as yellow solids in a $57 \%$ yield $(120 \mathrm{mg})$ and $55 \%$ yield $(111 \mathrm{mg})$, respectively.

Compound $11{ }^{1} \mathrm{H}$ NMR (600 MHz, DMSO-d 6 ): $\delta=11.16(\mathrm{~s}, 1 \mathrm{H}, \mathrm{NH}), 7.46\left(\mathrm{~d}, J_{\mathrm{H}, \mathrm{H}}=1.2\right.$ $\mathrm{Hz} 1 \mathrm{H}, \mathrm{H} 6$ thymine), $5.43\left(\mathrm{~d},{ }^{3} J_{\mathrm{H}, \mathrm{H}}=5.4 \mathrm{~Hz}, 1 \mathrm{H}, \mathrm{OH}\right), 5.08(\mathrm{~m}, 1 \mathrm{H}, \mathrm{Cp}), 5.06(\mathrm{~m}, 1 \mathrm{H}, \mathrm{Cp})$, 4.89 (m, 1H, Cp), 4.87 (m, 1H, Cp), $4.22(\mathrm{~m}, 1 \mathrm{H}, \mathrm{CH}), 3.81\left(\mathrm{~m}, 1 \mathrm{H}, \mathrm{CH}_{2}\right), 3.67\left(\mathrm{~m}, 1 \mathrm{H}, \mathrm{CH}_{2}\right)$, $1.92\left(\mathrm{~m}, 1 \mathrm{H}, \mathrm{CH}_{2}\right), 1.77\left(\mathrm{~m}, 1 \mathrm{H}, \mathrm{CH}_{2}\right), 1.75\left(\mathrm{~d}, J_{\mathrm{H}, \mathrm{H}}=0.6 \mathrm{~Hz}, 3 \mathrm{H}, \mathrm{CH}_{3}\right) .{ }^{13} \mathrm{C} \mathrm{NMR}(150 \mathrm{MHz}$, DMSO-d 6 ): $\delta=225.5,164.3,150.9,141.6,110.8,108.3,83.0,82.3,82.1,81.6,63.7,44.7$, 37.0, 11.9. (EI, 70eV): $\mathrm{m} / \mathrm{z}=386\left(\mathrm{M}^{+}\right), 302\left(\mathrm{M}^{+}-3 \mathrm{CO}\right)$. FTIR $(\mathrm{KBr}): 3430(\mathrm{OH}), 3170(\mathrm{CH})$, 
3028(CH), 2959(CH), 2930(CH), 2822(CH), 2015(CO), 1932(CO), 1913(CO), 1688(C=O), 1663(C=O), 1474, 1425, $1215 \mathrm{~cm}^{-1}$. Anal. Calcd for $\mathrm{C}_{16} \mathrm{H}_{15} \mathrm{~N}_{2} \mathrm{O}_{6} \mathrm{Mn}: \mathrm{C}, 49.76 ; \mathrm{H}, 3.91 ; \mathrm{N}$, 7.25\%. Found: C, $49.82 ; \mathrm{H}, 3.98 ; \mathrm{N}, 7.25 \%$.

Compound $12{ }^{1} \mathrm{H}$ NMR $\left(600 \mathrm{MHz}, \mathrm{DMSO}_{-} \mathrm{d}_{6}\right): \delta=10.98(\mathrm{~s}, 1 \mathrm{H}, \mathrm{NH}), 7.58\left(\mathrm{~d}, J_{\mathrm{H}, \mathrm{H}}=7.8\right.$ $\mathrm{Hz}, 1 \mathrm{H}, \mathrm{H} 6$ uracil), 5.53 (d, $J_{\mathrm{H}, \mathrm{H}}=7.8 \mathrm{~Hz}, 1 \mathrm{H}, \mathrm{H} 5$ uracil), $5.43\left(\mathrm{~d}, J_{\mathrm{H}, \mathrm{H}}=6.0 \mathrm{~Hz}, 1 \mathrm{H}, \mathrm{OH}\right)$, $5.09(\mathrm{~m} \mathrm{1H}, \mathrm{Cp}), 5.06(\mathrm{~m}, 1 \mathrm{H}, \mathrm{Cp}), 4.89\left(\mathrm{pq}, J_{\mathrm{H}, \mathrm{H}}=2.4 \mathrm{~Hz}, 1 \mathrm{H}, \mathrm{Cp}\right), 4.87\left(\mathrm{pq}, J_{\mathrm{H}, \mathrm{H}}=2.4 \mathrm{~Hz}\right.$, 1H, Cp), 4.22 (m, 1H, CH), $3.85\left(\mathrm{~m}, 1 \mathrm{H}, \mathrm{CH}_{2}\right), 3.70\left(\mathrm{~m}, 1 \mathrm{H}, \mathrm{CH}_{2}\right), 1.92\left(\mathrm{~m}, 1 \mathrm{H}, \mathrm{CH}_{2}\right), 1.77$ $\left(\mathrm{m}, 1 \mathrm{H}, \mathrm{CH}_{2}\right) .{ }^{13} \mathrm{C}$ NMR $\left(150 \mathrm{MHz}, \mathrm{DMSO}-\mathrm{d}_{6}\right): \delta=225.5,163.8,150.9,145.8,110.7,100.8$, 83.0, 82.4, 82.0, 81.7, 63.7, 45.0, 36.9. (EI, 70eV): $\mathrm{m} / \mathrm{z}=372\left(\mathrm{M}^{+}\right), 288\left(\mathrm{M}^{+}-3 \mathrm{CO}\right), 270\left(\mathrm{M}^{+}-\right.$ 3CO-H $\left.{ }_{2} \mathrm{O}\right)$. FTIR (KBr): 3377(OH), 3164(CH), 3049(CH), 2012(CO), 1936(CO), 1917(CO), 1695(C=O), 1663(C=O), 1470, 1420, 1375, $1296 \mathrm{~cm}^{-1}$. Anal. Calcd for $\mathrm{C}_{15} \mathrm{H}_{13} \mathrm{~N}_{2} \mathrm{O}_{6} \mathrm{Mn}: \mathrm{C}$, 48.40 ; H, 3.52 ; N, 7.53\%. Found: C, 48.16 ; H, 3.60 ; N, 7.37\%.

\section{General procedure for the synthesis of cyrhetrene alkohols 13 and 14}

To a stirred THF solution $(20 \mathrm{~mL})$ containing either 6 or $7(0.3 \mathrm{mmol}) \mathrm{Na}\left[\mathrm{BH}_{4}\right](19 \mathrm{mg}$, $0.5 \mathrm{mmol}$ ) was added in a single portion at ambient temperature. After $40 \mathrm{~min}$ of stirring, the reaction mixture was poured into $20 \mathrm{~mL}$ of water, extracted with chloroform (ca $40 \mathrm{~mL}$ ), dried over $\mathrm{MgSO}_{4}$ and evaporated to dryness. The residue was subjected to column chromatography on $\mathrm{SiO}_{2}$ (eluent chloroform-methanol 50/5 (v/v)). Crystallization from chloroform- $n$-pentane gave alcohols $\mathbf{1 3}$ and $\mathbf{1 4}$ as colourless solids in an 82\% yield (126 mg) and $79 \%$ yield $(113 \mathrm{mg})$, respectively.

Compound $13{ }^{1} \mathrm{H}$ NMR $\left(600 \mathrm{MHz}, \mathrm{DMSO}_{-} \mathrm{d}_{6}\right): \delta=11.16(\mathrm{~s}, 1 \mathrm{H}, \mathrm{NH}), 7.45\left(\mathrm{~d}, J_{\mathrm{H}, \mathrm{H}}=0.6\right.$ $\mathrm{Hz}, 1 \mathrm{H}, \mathrm{H} 6$ thymine), $5.72\left(\mathrm{pd}, J_{\mathrm{H}, \mathrm{H}}=2.4 \mathrm{~Hz}, 1 \mathrm{H}, \mathrm{Cp}\right), 5.68\left(\mathrm{pd}, J_{\mathrm{H}, \mathrm{H}}=2.4 \mathrm{~Hz}, 1 \mathrm{H}, \mathrm{Cp}\right), 5.54$ $(\mathrm{m}, 2 \mathrm{H}, \mathrm{Cp}), 5.51\left(\mathrm{~d}, J_{\mathrm{H}, \mathrm{H}}=6.0 \mathrm{~Hz}, 1 \mathrm{H}, \mathrm{OH}\right), 4.31(\mathrm{~m}, 1 \mathrm{H}, \mathrm{CH}), 3.80\left(\mathrm{~m}, 1 \mathrm{H}, \mathrm{CH}_{2}\right), 3.67(\mathrm{~m}$, $\left.1 \mathrm{H}, \mathrm{CH}_{2}\right), 1.93\left(\mathrm{~m}, 1 \mathrm{H}, \mathrm{CH}_{2}\right), 1.75\left(\mathrm{~s}, 3 \mathrm{H}, \mathrm{CH}_{3}\right), 1.73\left(\mathrm{~m}, 1 \mathrm{H}, \mathrm{CH}_{2}\right) .{ }^{13} \mathrm{C} \mathrm{NMR}(150 \mathrm{MHz}$, DMSO-d 6 ): $\delta=195.4,164.4,151.0,141.6,115.4,108.5,84.3,84.27,84.23,84.0,63.6,44.9$, 37.6, 12.0. MS (ESI): $\mathrm{m} / \mathrm{z}=541\left(\mathrm{M}+\mathrm{Na}^{+}\right)$. FTIR $(\mathrm{KBr}): 3414(\mathrm{OH}), 3107(\mathrm{CH}), 3009(\mathrm{CH})$, 2933(CH), 2832(CH), 2021(CO), 1942(CO), 1901(CO), 1674(C=O), 1671(C=O), 1484, 1429, 
$1369 \mathrm{~cm}^{-1}$. Anal. Calcd for $\mathrm{C}_{16} \mathrm{H}_{15} \mathrm{~N}_{2} \mathrm{O}_{6}$ Re: C, 37.13; H, 2.92; N, 5.41\%. Found: C, 36.87; H, $2.90 ; \mathrm{N}, 5.35 \%$.

Compound $14{ }^{1} \mathrm{H}$ NMR $\left(600 \mathrm{MHz}, \mathrm{DMSO}_{-} \mathrm{d}_{6}\right): \delta=11.17(\mathrm{~s}, 1 \mathrm{H}, \mathrm{NH}), 7.58\left(\mathrm{~d}, J_{\mathrm{H}, \mathrm{H}}=7.8\right.$ $\mathrm{Hz}, 1 \mathrm{H}, \mathrm{H} 6$ uracil), $5.73\left(\mathrm{pd}, J_{\mathrm{H}, \mathrm{H}}=2.0 \mathrm{~Hz}, 1 \mathrm{H}, \mathrm{Cp}\right), 5.69\left(\mathrm{pd}, J_{\mathrm{H}, \mathrm{H}}=2.0 \mathrm{~Hz}, 1 \mathrm{H}, \mathrm{Cp}\right), 5.53$ (m, 4H, OH, Cp, H5 uracil), $4.31(\mathrm{~m}, 1 \mathrm{H}, \mathrm{CH}), 3.85\left(\mathrm{~m}, 1 \mathrm{H}, \mathrm{CH}_{2}\right), 3.70\left(\mathrm{~m}, 1 \mathrm{H}, \mathrm{CH}_{2}\right), 1.93$ (m, 1H, $\mathrm{CH}_{2}$ ), 1.74 (m, 1H, $\left.\mathrm{CH}_{2}\right) .{ }^{13} \mathrm{C}$ NMR (150 MHz, DMSO-d 6 ): $\delta=195.4,163.8,151.0$, 145.9, 115.3, 100.9, 84.3, 84.27, 84.25, 84.0, 63.6, 45.2, 37.5. (EI, 70eV): m/z = 504(M $\left.{ }^{+}\right)$,

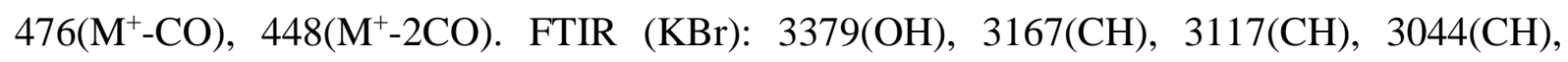
2952(CH), 2927(CH), 2851(CH), 2018(CO), 1926(CO), 1901(CO), 1692(C=O), 1660(C=O) $\mathrm{cm}^{-1}$. Anal. Calcd for $\mathrm{C}_{15} \mathrm{H}_{13} \mathrm{~N}_{2} \mathrm{O}_{6}$ Re: $\mathrm{C}, 35.78 ; \mathrm{H}, 2.60 ; \mathrm{N}, 5.56 \%$. Found: C, 36.01; H, 2.67; N. $5.54 \%$.

\section{Synthesis of cymantrene alcohol (15)}

To a stirred solution of 5 (212 mg, $0.5 \mathrm{mmol})$ in THF $(25 \mathrm{~mL}) \mathrm{Li}\left[\mathrm{AlH}_{4}\right](1 \mathrm{M})$ in THF $(0.5$ $\mathrm{mL}, 0.5 \mathrm{mmol}$ ) was added at ambient temperature. The respective reaction mixture was stirred for $8 \mathrm{~min}$ and $25 \mathrm{~mL}$ of methanol-water $1 / 1(v / v)$ were added. The organic phase was extracted with chloroform (ca $40 \mathrm{~mL}$ ), dried over $\mathrm{MgSO}_{4}$ and evaporated to dryness. The residue was subjected to column chromatography on $\mathrm{SiO}_{2}$ (eluent chloroform-methanol 50/3 $(v / v))$. Crystallization from chloroform- $n$-hexane $c a .1 / 2(v / v)$ gave 15 as a yellow solid in an $81 \%$ yield $(395 \mathrm{mg})$.

Compound $15{ }^{1} \mathrm{H}$ NMR (600 MHz, DMSO-d 6 ): $\delta=8.13$ (s, 1H, H2 adenine), 8.11 (s, 1H, $\mathrm{H} 8$ adenine), $7.13\left(\mathrm{~s}, 2 \mathrm{H}, \mathrm{NH}_{2}\right), 5.58\left(\mathrm{~d}, J_{\mathrm{H}, \mathrm{H}}=6.0 \mathrm{~Hz}, 1 \mathrm{H}, \mathrm{OH}\right), 5.09(\mathrm{~s}, 1 \mathrm{H}, \mathrm{Cp}), 5.05(\mathrm{~s}, 1 \mathrm{H}$, $\mathrm{Cp}), 4.87\left(\mathrm{pd}, J_{\mathrm{H}, \mathrm{H}}=1.8 \mathrm{~Hz}, 1 \mathrm{H}, \mathrm{Cp}\right), 4.85\left(\mathrm{pd}, J_{\mathrm{H}, \mathrm{H}}=1.8 \mathrm{~Hz}, 1 \mathrm{H}, \mathrm{Cp}\right), 4.26\left(\mathrm{~m}, 2 \mathrm{H}, \mathrm{CH}_{2}\right)$, $4.18(\mathrm{~m}, 1 \mathrm{H}, \mathrm{CH}), 2.18\left(\mathrm{~m}, 1 \mathrm{H}, \mathrm{CH}_{2}\right), 1.98\left(\mathrm{~m}, 1 \mathrm{H}, \mathrm{CH}_{2}\right) .{ }^{13} \mathrm{C} \mathrm{NMR}\left(150 \mathrm{MHz}, \mathrm{DMSO}-\mathrm{d}_{6}\right): \delta$ $=225.4,156.0,152.4,149.7,141.1,119.2,110.5,83.0,82.4,82.0,81.5,63.5,40.0,38.0$. MS (EI, 70eV): m/z = $395\left(\mathrm{M}^{+}\right), 311\left(\mathrm{M}^{+}-3 \mathrm{CO}\right)$. FTIR (KBr): 3370(OH), 3316, 3117, 2974(CH), 2939(CH), 2018(CO), 1923(CO), 1651(NH), 1591(NH) $\mathrm{cm}^{-1}$. Anal. Calcd for $\mathrm{C}_{16} \mathrm{H}_{14} \mathrm{~N}_{5} \mathrm{O}_{4} \mathrm{Mn}: \mathrm{C}, 48.62$; H, 3.57 ; N, 17.72\%. Found: C, 48.68 ; H, 3.69 ; N, $17.56 \%$. 
Alcohol 15 (150 mg, $0.38 \mathrm{mmol})$ and 1,2-bis(diphenylphosphino)ethane (167 mg, 0.42 mmol) dissolved in anhydrous and argon-saturated THF $(50 \mathrm{~mL})$ were photolysed with a 200 $\mathrm{W}$ high-pressure mercury lamp for $2 \mathrm{~h}$. The solvent was evaporated to dryness. The residue was subjected to column chromatography on $\mathrm{SiO}_{2}$ (eluent chloroform-methanol 50/3 $(v / v)$ ). Crystallization from chloroform- $n$-hexane gave crude 16. Subsequently purification of 16 was conducted by normal phase HPLC with Luna 5u Silica (2) 100A, AXIA Packed 150 X 21.1 mm preparative column. A mixture of dichloromethane (97\%) and methanol (3\%) and low pressure gradient with total flow pump $10 \mathrm{~mL} / \mathrm{min}$ was used. Crystallization from $n$-hexane gave $\mathbf{1 6}$ as an orange solid in a $37 \%$ yield (104 $\mathrm{mg})$.

${ }^{1} \mathrm{H}$ NMR (600 MHz, DMSO-d 6 ): $\delta=8.10$ (s, 1H, H2 adenine), 7.99 (s, 1H, H8 adenine), 7.69(pt, $\left.J_{\mathrm{H}, \mathrm{H}}=6.6 \mathrm{~Hz}, 2 \mathrm{H}, \mathrm{Ph}\right), 7.65\left(\mathrm{pt}, J_{\mathrm{H}, \mathrm{H}}=6.6 \mathrm{~Hz}, 2 \mathrm{H}, \mathrm{Ph}\right), 7.31(\mathrm{~m}, 12 \mathrm{H}, \mathrm{Ph}), 7.13(\mathrm{~s}, 2 \mathrm{H}$, $\left.\mathrm{NH}_{2}\right), 7.08(\mathrm{~m}, 4 \mathrm{H}, \mathrm{Ph}), 4.97\left(\mathrm{~d},{ }^{3} J_{\mathrm{H}, \mathrm{H}}=6.0 \mathrm{~Hz}, 1 \mathrm{H}, \mathrm{OH}\right), 4.46(\mathrm{~s}, 1 \mathrm{H}, \mathrm{Cp}), 4.38(\mathrm{~s}, 1 \mathrm{H}, \mathrm{Cp})$, $4.22\left(\mathrm{~m}, 2 \mathrm{H}, \mathrm{CH}_{2}\right), 4.16(\mathrm{~m}, 1 \mathrm{H}, \mathrm{CH}), 3.59(\mathrm{~s}, 1 \mathrm{H}, \mathrm{Cp}), 3.30(\mathrm{~s}, 1 \mathrm{H}, \mathrm{Cp}), 2.41\left(\mathrm{~m}, 2 \mathrm{H}, \mathrm{CH}_{2}\right.$ dppe), 2.15(m, 2H, $\mathrm{CH}_{2}$ dppe), 2.10(m, $\left.1 \mathrm{H}, \mathrm{CH}_{2}\right), 1.98\left(\mathrm{~m}, 1 \mathrm{H}, \mathrm{CH}_{2}\right) .{ }^{13} \mathrm{C} \mathrm{NMR}(150 \mathrm{MHz}$, DMSO-d $\left.{ }_{6}\right): \delta=233.1\left(J_{\mathrm{P}, \mathrm{C}}=24 \mathrm{~Hz}\right), 156.0,152.3,149.6,142.8,140.7,140.1-139.8(\mathrm{~m})$, $132.5\left(\mathrm{~d}, J_{\mathrm{P}, \mathrm{C}}=9 \mathrm{~Hz}\right), 132.4\left(\mathrm{~d}, J_{\mathrm{P}, \mathrm{C}}=10 \mathrm{~Hz}\right), 130.8\left(\mathrm{~d}, J_{\mathrm{P}, \mathrm{C}}=7 \mathrm{~Hz}\right), 129.0\left(\mathrm{~d}, J_{\mathrm{P}, \mathrm{C}}=3 \mathrm{~Hz}\right)$, $128.7\left(\mathrm{~d}, J_{\mathrm{P}, \mathrm{C}}=7 \mathrm{~Hz}\right), 128.4\left(\mathrm{~d}, J_{\mathrm{P}, \mathrm{C}}=3 \mathrm{~Hz}\right), 128.0\left(\mathrm{~d}, J_{\mathrm{P}, \mathrm{C}}=6 \mathrm{~Hz}\right), 127.9\left(\mathrm{~d}, J_{\mathrm{P}, \mathrm{C}}=7 \mathrm{~Hz}\right), 101.3$, 79.1, 78.6, 78.0, 75.6, 65.3, 40.3, 37.2, 29.7-29.4 (m). ${ }^{31} \mathrm{P}\left\{{ }^{1} \mathrm{H}\right\} \mathrm{NMR}$ (243 MHz, DMSO-d 6 ): $\delta=116.27\left(\mathrm{~d}, J_{\mathrm{P}, \mathrm{P}}=15.3 \mathrm{~Hz}, \mathrm{dppe}\right), 115.99\left(\mathrm{~d}, J_{\mathrm{P}, \mathrm{P}}=15.3 \mathrm{~Hz}, \mathrm{dppe}\right) . \mathrm{MS}(\mathrm{EI}, 70 \mathrm{eV}): \mathrm{m} / \mathrm{z}=$ 737( $\left.\mathrm{M}^{+}\right)$, 691( $\left.\mathrm{M}^{+}-\mathrm{CO}-\mathrm{H}_{2} \mathrm{O}\right)$. FTIR (KBr): 3376(OH), 3072, 3053, 2955(CH), 2927(CH), 2857(CH), 1926, 1834(CO), 1635(NH), 1597(NH), 1480, 1435, $698 \mathrm{~cm}^{-1}$. Anal. Calcd for $\mathrm{C}_{40} \mathrm{H}_{38} \mathrm{~N}_{5} \mathrm{O}_{2} \mathrm{P}_{2} \mathrm{Mn}: \mathrm{C}, 65.13 ; \mathrm{H}, 5.19 ; \mathrm{N}, 9.49 \%$. Found: C, $65.07 ; \mathrm{H}, 5.32 ; \mathrm{N}, 9.20 \%$.

\section{Single-crystal X-ray structure of 5}

The crystal structure of $\mathbf{5}$ was solved by the Patterson method and refined on F2 by fullmatrix least-squares procedures using SHELXL. ${ }^{[37]}$ All non-hydrogen atoms were refined with anisotropic displacement parameters. Carbon bonded hydrogen atoms were introduced in calculated positions with idealized geometry and constrained using a rigid body model with isotropic displacement parameters equal to 1.2 of the equivalent displacement parameters of the parent atoms. Positions amine NH hydrogen atoms were found on the Fourier difference map and refined. The molecular geometries were calculated by programs implemented in WinGX system. ${ }^{[38]}$ A summary of relevant crystallographic data is given in Table $\mathrm{S} 1$. 


\section{Notice}

Atoms' coordinates and displacement parameters, and supplementary crystallographic data are deposited with Cambridge Crystallographic Data Centre under the number CCDC 1485427. The data can be obtained free of charge via http://www.ccdc.cam.ac.uk/conts/retrieving.html (or from the Cambridge Crystallographic Data Centre, 12, Union Road, Cambridge CB2 1EZ, UK; fax: +44 1223 336033).

\section{Acknowledgement}

K.K. and Ł.Sz. thank the National Science Centre (Kraków, Poland) for financial support (Grant no. DEC-2013/11/B/ST5/00997).

Keywords: bioorganometallic chemistry, cymantrene, cyrhetrene, ferrocene, nucleobases, antitrypanosomal activity

\section{References}

[1] a) G. Jaouen, M. Salmain (Eds.), Bioorganometallic Chemistry. Applications in Dug Discovery, Biocatalysis, and Imaging, Wiley-VCH, Weinheim, Germany, 2015; b) G. Jaouen (Ed.), Bioorganometallics: Biomolecules, Labeling, Medicine, Wiley-VCH, Weinheim, 2006.

[2] a) C. Ornelas, New J. Chem. 2011, 35, 1973-1985; b) A. Gautier, F. Cisnetti, Metallomics 2012, 4, 23-32; c) I. Ott, Coord. Chem. Rev. 2009, 253, 1670-1681; d) W. Liu, R. Gust, Chem. Soc. Rev. 2013, 42, 755-773; e) G. Jaouen, A. Vessières, S. Top, Chem. Soc. Rev. 2015, 44, 8802-8817; f) G. Palermo, A. Magistrato, T. Riedel, T. von Erlach, C. A. Davey, P.J. Dyson, U. Rothlisberger, ChemMedChem 2016, 11, 1199-1210; g) J. Furrer, G. SüssFink, Coord. Chem. Rev. 2016, 309, 36-50.

[3] a) M. Patra, G. Gasser, N. Metzler-Nolte, Dalton. Trans. 2012, 41, 6350-6358; b) M. Tacke, J. Organomet. Chem. 2015, 782, 17-21.

[4] a) R.W. Brown, C. J. T. Hyland, MedChemComm. 2015, 6, 1230-1243; b) F. Dubar, Ch. Biot, Bioorganometallic Chemistry. Applications in Dug Discovery, Biocatalysis, and Imaging, (Eds.: G. Jaouen, M. Salmain), Wiley-VCH, Weinheim, Germany, 2015. 
[5] a)V. Fernández-Moreira, F. L. Thorp-Greenwood, M. P. Coogan, Chem.Commun. 2010, 46, 186-202; b) E. Baggaley, J.A. Weinstein, J.A. Gareth Williams, Coord. Chem. Rev. 2012, 256, 1762-1785; c) K. K.-W. Lo, Acc. Chem. Res. 2015, 48, 2985-2995.

[6] A. Leonidova, V. Pierroz, R. Rubbiani, J. Heier, S. Ferrari, G. Gasser, Dalton. Trans., 2014, 43, 4287-4294.

[7] A. Leonidova, C. Mari, C. Aebersold, G. Gasser, Organometallics 2016, 35, 851-854.

[8] F. Le Bideau, M. Salmain, S. Top, G. Jaouen, Chem. Eur. J. 2001, 7, 2289-2294.

[9] K. Wu, S. Top, E.A. Hillard, G. Jaouen, W.E. Geiger, Chem.Commun., 2011, 47, 1010910111.

[10] C. Policar, B. J. Waern, M.-A. Plamont, S. Clède, C. Mayet, R. Prazeres, J.-M. Ortega, A. Vessières, A. Dazzi, Angew. Chem. Int. Ed. 2011, 50, 860-864.

[11] G. Jaouen, S. Top, M. J. McGlinchey, Bioorganometallic Chemistry. Applications in Dug Discovery, Biocatalysis, and Imaging, (Eds.: G. Jaouen, M. Salmain), Wiley-VCH, Weinheim, Germany, 2015.

[12] D. Can, B. Spingler, P. Schmutz, F. Mendes, P. Raposinho, C. Fernandes, F. Carta, A. Innocenti, I. Santos, C.T. Supuran, R. Alberto, Angew. Chem. Int. Ed. 2012, 51, 3354-3357. [13] S. Splith, I. Neundorf, W. Hu, H.W. Peindy N’Dongo, V. Vasylyeva, K. Merz, U. Schatzschneider, Dalton Trans. 2010, 39, 2536-2545.

[14] I. Neundorf , J. Hoyer, K. Splith, R. Rennert, H.W. Peindy N’Dongo and U. Schatzschneider, Chem. Commun. 2008, 5604-5606.

[15] a) M. Patra, G. Gasser, M. Wenzel, K. Merz, J.E. Bandow, N. Metzler-Nolte, Organometallics 2012, 31, 5760-5771; b) M. Wenzel, M. Patra, C.H.R. Sengers, I. Ott, J.J. Stepanek, A. Pinto, P. Prochnow, C. Vuong, S. Langklotz, N. Metzler-Nolte, J.E. Bandow, ACS Chem. Biol. 2013, 8, 1442-1450; c) M. Patra, M. Wenzel, P. Prochnow, V. Pierroz, G. Gasser, J.E. Bandow, N. Metzler-Nolte, Chem. Sci. 2015, 6, 214-224. 
[16] a) R. Arancibia, F. Dubar, B. Pradines, J. Forfar, D. Dive, A.H. Klahn, C. Biot, Bioorg.

Med. Chem. 2010, 18, 8085-8091; b) R. Arancibia, A.H. Klahn, G.E. Buono-Core, E.

Gutierrez-Puebla, A. Monge, M.E. Medina, C. Olea-Azar, J.D. Maya, F. Godoy, J.

Organomet. Chem. 2011, 696, 3238-3244; c) R. Arancibia, A.H. Klahn, G.E. Buono-Core, D.

Contreras, G. Barriga, C. Olea-Azar, M. Lapier, J.D. Maya, A. Ibañez and M.T. Garland, J.

Organomet. Chem. 2013, 743, 49-54; d) L. Glans, W. Hu, C. Jöst, C. de Kock, P.J. Smith, M.

Haukka, H. Bruhn, U. Schatzschneider and E. Nordlander, Dalton Trans. 2012, 41, 6443-

6450; e) D.P. Day, T. Dann, D.L. Hughes, V.S. Oganesyan, D. Steverding and G.G.

Wildgoose, Organometallics 2014, 33, 4687-4696.

[17] a) K. Kowalski Coord. Chem. Rev. 2016, 317, 132-156; b) M. Hocek, P. Štěpnička, J.

Ludvík, I. Císařová, I. Votruba, D. Řeha, P. Hobza Chem. Eur. J. 2004, 10, 2058-2066; c) K.

Kowalski, J. Skiba, L. Oehninger, I. Ott, J. Solecka, A. Rajnisz, B. Therrien, Organometallics, 2013, 32, 5766-5773; d) J. Skiba, C. Schmidt, P. Lippmann, P. Ensslen, H.-A. Wagenknecht, R. Czerwieniec, F. Brandl, I. Ott, T. Bernaś, B. Krawczyk, D. Szczukocki, K. Kowalski, Eur. J. Inorg. Chem. 2016, DOI:10.1002/ejic.201600281.

[18] M. Rosenblum, Chemistry of the iron group metallocenes. Part One, Wiley, New York, US, 1965.

[19] J. Kumar, Ch.S. Purohit, S. Verma, ChemCommun. 2008, 2526-2528.

[20] a) G. Teixeira, T. Avilés, A. R. Dias, F. Pina, J. Organomet. Chem. 1988, 353, 83-91; b) M. Herberhold, W. Kremnitz, H. Trampisch, R. B. Hitam, A. J. West, D. J. Taylor, J. Chem.Soc., Dalton Trans. 1982, 1261-1273; c) B. S. Creaven, A. J. Dixon, J. M. Kelly, C. Long, M. Poliakoff, Organometallics, 1987, 6, 2600-2605.

[21] a) R.J. LeSuer, C. Buttolph, W.E. Geiger, Anal. Chem. 2004, 76, 6395-6401; b) F. Barrière, W.E. Geiger. J. Am. Chem. Soc. 2006, 128, 3980-3989; c) H.J. Gericke, N.I. Barnard, E. Erasmus, J.C. Swarts, M.J. Cook, M.A.S. Aquino, Inorg. Chim. Acta 2010, 363, 2222-2232; d) E. Fourie, J.C. Swarts, D. Lorcy, N. Bellec, Inorg. Chem. 2010, 49, 952-959; e) U. Pfaff, A. Hildebrandt, D. Schaarschmidt, T. Rüffer, P. J. Low, H. Lang Organometallics 2013, 32, 6106-6117; f) D. Miesel, A. Hildebrandt, M. Korb, P. J. Low, H. Lang Organometallics 2013, 32 2993-3002; g) A. Hildebrandt, K. Al Khalyfeh, D. Schaarschmidt, 
M. Korb J. Organomet. Chem. 2016, 804, 87-94; h) U. Pfaff, A. Hildebrandt, M. Korb, S. Oßwald, M. Linseis, K. Schreiter, S. Spange, R. F. Winter, H. Lang Chem. Eur. J. 2016, 22, 783-801.

[22] G. Gritzner, J. Kuta, J. Pure Appl. Chem. 1984, 56, 461-467.

[23] D. R. Laws, D. Chong, K. Nash, A. L. Rheingold, W. E. Geiger, J. Am. Chem. Soc. 2008, 130, 9859-9870.

[24] K. Wu, D. R. Laws, A. Nafady, W. E. Geiger, J. Inorg. Organomet. Polym. Mater. 2014, $24,137-144$.

[25] H. Hirumi, K. Hirumi, J. J. Doyle,G. A. M. Cross, Parasitology, 1980, 80, 371-382.

[26] S. J. Collins, R. C. Gallo, R. E. Gallagher, Nature, 1977, 270, 347-349.

[27] D. Steverding, X. Wang, Parasit. Vectors 2009, 2, 29.

[28] Gaussian 09, Revision D.01, M. J. Frisch, G. W. Trucks, H. B. Schlegel, G. E. Scuseria, M. A. Robb, J. R. Cheeseman, G. Scalmani, V. Barone, B. Mennucci, G. A. Petersson, H. Nakatsuji, M. Caricato, X. Li, H. P. Hratchian, A. F. Izmaylov, J. Bloino, G. Zheng, J. L. Sonnenberg, M. Hada, M. Ehara, K. Toyota, R. Fukuda, J. Hasegawa, M. Ishida, T. Nakajima, Y. Honda, O. Kitao, H. Nakai, T. Vreven, J. A. Montgomery, Jr., J. E. Peralta, F. Ogliaro, M. Bearpark, J. J. Heyd, E. Brothers, K. N. Kudin, V. N. Staroverov, R. Kobayashi, J. Normand, K. Raghavachari, A. Rendell, J. C. Burant, S. S. Iyengar, J. Tomasi, M. Cossi, N. Rega, J. M. Millam, M. Klene, J. E. Knox, J. B. Cross, V. Bakken, C. Adamo, J. Jaramillo, R. Gomperts, R. E. Stratmann, O. Yazyev, A. J. Austin, R. Cammi, C. Pomelli, J. W. Ochterski, R. L. Martin, K. Morokuma, V. G. Zakrzewski, G. A. Voth, P. Salvador, J. J. Dannenberg, S. Dapprich, A. D. Daniels, Ö. Farkas, J. B. Foresman, J. V. Ortiz, J. Cioslowski, and D. J. Fox, Gaussian, Inc., Wallingford CT, 2009.

[29] A. D. Becke, J. Chem. Phys., 1993, 98, 5648-5652.

[30] M. Cossi, N. Rega, G. Scalmani, and V. Barone, J. Comp. Chem., 2003, 24, 669-81.

[31] I. M. Alecu, J. Zheng, Y. Zhao, and D. G. Truhlar, J. Chem. Theory Comput., 2010, 6, 2872-2887.

[32] A. J. H. Wachters, J. Chem. Phys., 1970, 52, 1033-1036.

[33] A. Nafady, W. E. Geiger, Organometallics, 2008, 27, 5624-5631.

[34] T. Baltz, D. Baltz, C. Giroud, J. Crockett, EMBO J. 1985, 4, 1273-1277.

[35] G.E. Moore, R. E. Gerner, H. A. Franklin, J. Am. Med. Assoc., 1967, 199, 519-524.

[36] W. Huber, J. C. Koella, Acta Trop. 1993, 55, 257-262.

[37] G. M. Sheldrick, Acta Crystallogr., Sect. A: Fundam. Crystallogr. 2008, 64, 112-122. 
[38] L. J. Farrugia, J. Appl. Crystallogr. 1999, 32, 837-838.

\section{Graphical abstract}

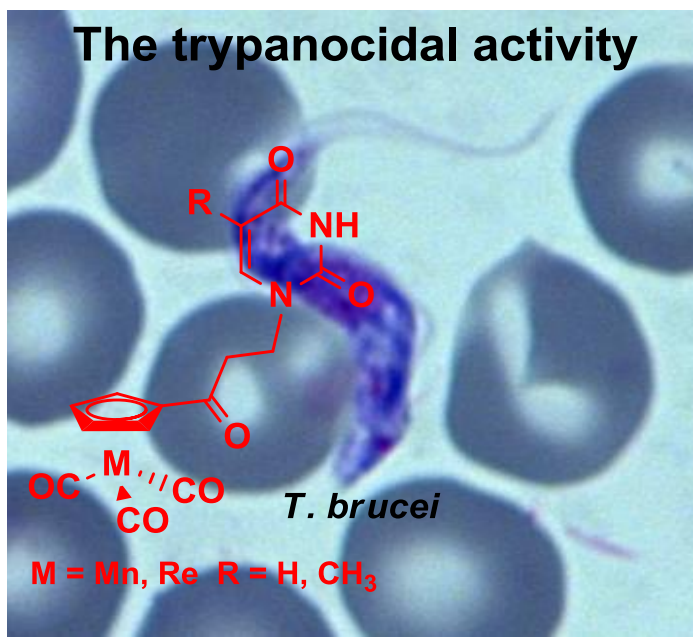

Cymantrene, cyrhetrene and ferrocene nucleobase conjugates have been synthesised and studied by electrochemistry and DFT calculations. Some compounds exhibit significant activity against $T$. bruce $i$ a causative parasite of sleeping sickness. 